\title{
Caesalpinieae (Leguminosae-Caesalpinioideae) do Campo Experimental da Embrapa Amazônia Oriental, Município de Moju, PA, Brasil
}

\author{
Maira dos Santos Rodrigues ${ }^{1,3}$, Regina Célia Martins-da-Silva ${ }^{2}$ e Ricardo de Souza Secco ${ }^{1}$
}

Recebido: 9.11.2011; aceito: 13.09.2012

\begin{abstract}
Caesalpinieae (Leguminosae-Caesalpinioideae) from the Experimental field of the Embrapa Eastern Amazon, Moju, Pará State, Brazil). The present study carried out a floristic-taxonomic study of the tribe Caesalpinieae at Campo Experimental da Embrapa Amazônia Oriental, Moju, Pará State as a complement of the floristic surveys initiated in 2001. The study also contributes to the knowledge of Leguminosae from the State of Pará. Collection activities were performed by using conventional techniques for plant taxonomy. The plants collected were first identified at the IAN and MG herbaria by comparison with previously identified specimens and then by specific literature and morphotype analysis. Caesalpineae is represented, so far, by 10 taxa of which Batesia, Campsiandra, Dimorphandra, Libidibia and Vouacapoua have only one species; Tachigali is represented by five species. Dimorphandra macrostachya ssp. congestiflora is a new record for the State of Pará. The research includes descriptions and keys for the taxa identification, detailed illustrations, area of occurrence, list of material examined and comments for each studied taxon.
\end{abstract}

Key words: Amazon, flora, floristic inventory, Leguminosae

RESUMO - (Caesalpinieae (Leguminosae-Caesalpinioideae) do Campo Experimental da Embrapa Amazônia Oriental, Município de Moju, PA, Brasil). Este trabalho tem como objetivo realizar o estudo florístico-taxonômico da tribo Caesalpinieae, do Campo Experimental da Embrapa Amazônia Oriental, Moju, PA, complementando o conhecimento da flora local, cujo inventário teve início em 2001; visa também contribuir para o conhecimento das Leguminosae do Estado do Pará. As coletas foram feitas através de técnicas convencionais utilizadas em taxonomia vegetal. A identificação dos espécimes foi realizada, inicialmente, nos herbários IAN e MG, comparando-se com material previamente determinado; a seguir, utilizou-se literatura específica e comparação com os tipos. Caesalpinieae está representada na área por 10 táxons, dos quais Batesia, Campsiandra, Dimorphandra, Libidibia e Vouacapoua apresentam apenas uma espécie cada; Tachigali está representado por cinco espécies. Dimorphandra macrostachya ssp. congestiflora é um novo registro para o Estado do Pará. Neste trabalho são apresentadas descrições e chave para identificação dos táxons estudados, ilustrações detalhadas, área de ocorrência, lista do material examinado e comentários sobre cada táxon tratado.

Palavras-chave: Amazônia, flora, Leguminosae, levantamento florístico

\section{Introdução}

Caesalpinieae é uma das quatro tribos de Caesalpinioideae, pertencente às Leguminosae, compreendendo 56 gêneros, 23 dos quais são monoespecíficos, e aproximadamente 436 espécies. A maioria dos gêneros e $71 \%$ das espécies ocorrem no Novo Mundo (Lewis et al. 2005).

De acordo com Lima et al. (2010e), Caesalpinieae está representada no Brasil por aproximadamente
130 spp., pertencentes a 25 gêneros; no Pará, ocorrem 33 espécies distriuídas nos gêneros Batesia Spruce ex Benth. (1 espécie), Caesalpinia L. (1), Campsiandra Benth. (5), Cenostigma Tul. (1), Dimorphandra Schott (9), Jacqueshuberia Ducke (1), Mora Schomb. ex Benth. (1), Poincianella Britton \& Rose (1), Schizolobium Vogel (1) e Tachigali Aubl. (12 espécies).

Segundo Polhill \& Vidal (1981), Caesalpinieae compreende oito grupos informais: Acrocarpus,

1. Museu Paraense Emilio Goeldi, Av. Perimetral 1901, 66077-830 Belém, PA, Brasil

2. Embrapa Amazônia Oriental, Trav. Dr. Enéas Pinheiro s/nº , Caixa Postal 48, 66095-100 Belém, PA, Brasil

3. Autor para correspondência: maira_rodrigues@yahoo.com.br 
Poeppigia e Pterogyne (monogenéricos), Gleditsia (dois gêneros), Sclerolobium (três), Dimorphandra (10), Peltophorum (13) e Caesalpinia (16). Entretanto, Lewis et al. (2005), apesar de manterem, em parte, tais grupos, propuseram algumas modificações como para os grupos Gleditsia e Acrocarpus, que foram incorporados ao clado Umtiza; Diptychandra Tul. foi retirado do grupo Sclerolobium, sendo posicionado fora dos grupos juntamente com mais quatro gêneros; o grupo Sclerolobium foi transferido para Tachigali; o grupo Caesalpinia foi ampliado para 21 gêneros e Poeppigia C. Presl foi transferido para Cassieae.

Em estudos cladísticos, Doyle (1994) demostrou que nessa tribo existem táxons basais dentro da família. Doyle et al. (2000), estudando os genes $r b c \mathrm{~L}$ associados a dados morfológicos, consideraram não mais Caesalpinieae como uma tribo basal na sub-família, mas Cercideae, embora com baixa sustentação de bootstrap.

Muitas espécies de Caesalpinieae apresentam importância econômica, sendo empregadas na construção civil, a exemplo de Campsiandra laurifolia Benth. (Ducke 1949). Vouacapoua americana Aubl. é considerada uma das madeiras mais importantes para o comércio paraense, sendo utilizada na carpintaria (construção civil e naval), marcenaria na produção de tacos de assoalhos, bilhar e outros objetos decorativos (Rizzini 1990, Rizzini \& Mors 1995). Caesalpinia ferrea (atualmente, Libidibia ferrea (Mart. ex Tul.) L.P. Queiroz) é empregada na ornamentação de praças e vias públicas (Rizzini \& Mors 1995), na indústria farmacêutica (Prance \& Silva 1975) e também pode ser aproveitada para plantio em áreas degradadas visando à recuperação da vegetação (Lorenzi 2002).

As Leguminosae da Amazônia têm recebido a atenção de vários autores como Ducke (1922, 1944, 1949), Prance \& Silva (1975), Silva et al. (1989), Costa et al. (1998), Almeida et al. (2001), Serrão et al. (2003), Martins-da-Silva et al. (2008) e Freitas (2009), nas mais diversas áreas. Porém, ainda é necessário ampliar o conhecimento taxonômico dessa família, principalmente em Caesalpinieae, uma vez que pouco se conhece sobre alguns gêneros, tais como Campsiandra, Chidlowia Hoyle, Diptychandra Tul., Orphanodendron Barneby \& J.W. Grimes e Vouacapoua (Lewis et al. 2005).

Devido à carência de informação taxonômica sobre alguns gêneros dessa tribo e visto que o Campo Experimental da Embrapa Amazônia Oriental (Moju, PA) é uma área destinada a estudos científicos, que foi inventariada no período de 2001-2004 (Projeto
Dendrogene - Embrapa/DFD), com a finalidade de se elaborar uma flora, este trabalho tem como objetivo realizar o estudo florístico-taxonômico das espécies, subespécies e variedades de Caesalpinieae na área. Visa, também, contribuir para o conhecimento de Leguminosae do Estado do Pará.

\section{Material e métodos}

O trabalho foi desenvolvido no Campo Experimental da Embrapa Amazônia Oriental, localizado às margens da rodovia PA-150, no município de Moju, Estado do Pará, situado entre as coordenadas geográficas de $2^{\circ} 08^{\prime} 14^{\prime \prime}-2^{\circ} 12^{\prime} 26^{\prime \prime} \mathrm{S}$

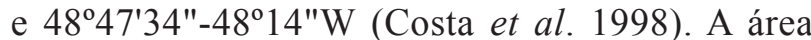
tem 1.059 ha (figura 1), apresenta relevo plano com pequenos declives de $0 \%$ a $3 \%$ e solo é predominantemente Latossolo Amarelo (Almeida et al. 2001). A cobertura vegetal da região consiste de floresta tropical densa de terra firme, constituída por árvores de grande porte, com altura entre 25 e $35 \mathrm{~m}$ (Serrão et al. 2003).

O município de Moju é servido pelo rio Moju, que nasce no município de Rondon do Pará, com o qual o município faz limite a Sudeste, e deságua no rio Guairá, no município Barcarena. Moju dista 117 km em linha reta da capital estadual (Costa et al. 1998). O clima da região é do tipo mesotérmico e úmido, a temperatura média anual é elevada, em torno de $25^{\circ} \mathrm{C}$ e seu regime pluviométrico anual está, geralmente, próximo dos $2.250 \mathrm{~mm}$; as chuvas, apesar de regulares, não se distribuem igualmente durante o ano; a umidade relativa do ar é em média de $85 \%$ (SEPOF 2009).

As coletas foram realizadas em quatro expedições no ano de 2010, a primeira no período de 05-16 de abril, a segunda de 15-18 de junho, a terceira de 7-9 de julho e a quarta de 16-20 de agosto. Foram realizadas coletas nas 11 trilhas existentes na área e também nos ramais. Cada trilha possui cerca de $2.000 \mathrm{~m}$ de extensão e a cada $50 \mathrm{~m}$ há um piquete que indica o percurso dentro da trilha. Além das amostras coletadas para este trabalho, foi analisado material do acervo do Herbário IAN, coletado na mesma área, durante o Projeto Dendrogene (Embrap/DFID), no período de 2001 a 2004.

As coletas e tratamento das amostras botânicas seguiram metodologia clássica adotada para estudos taxonômicos (Mori et al. 1989); os exemplares foram registrados e incorporados no acervo do IAN e as duplicatas foram enviadas para os herbários MG, RB e INPA. 
A identificação do material examinado foi obtida por consulta à literatura taxonômica, por comparação com material do acervo dos herbários IAN e MG e, quando possível, foi confrontado com material-tipo ou fotografia do mesmo; em alguns casos, por consulta a especialista.

A terminologia utilizada para a descrição dos táxons está de acordo com Stearn (1998) e Harris \& Harris (2001) com exceção de fruto que seguiu Barroso et al. (1999).

Leguminosae foi considerada como uma família com três subfamílias de acordo com APG III (2009), para a classificação em subfamília e tribo seguiu-se Lewis et al. (2005). A descrição da tribo foi baseada apenas nos táxons de Caesalpinieae encontrados na área de estudo.
Das espécies que não foram coletadas com flor ou fruto na área de estudo, utilizou-se material adicional oriundo de outras áreas para descrever tais estruturas, como por exemplo: Batesia floribunda Spruce ex Benth. (N.T. Silva 833 IAN - fruto e semente); Campsiandra laurifolia Benth. (M.S. Rodrigues 395 IAN - flor), (J.M. Pires 14118 IAN semente); Libidibia ferrea (Mart. ex Tul.) L.P. Queiroz (M.S. Rodrigues \& J.C.L. Oliveira 379 IAN - flor), (M.S. Rodrigues \& M.P. Nascimento 372 IAN semente); Tachigali alba Ducke (descrição de Dwyer (1954) - fruto); Tachigali guianensis (Benth.) Zarucchi \& Herend. (Lanjouw, 1239 IAN - flor), (N.A. Rosa 252 IAN - fruto), (R.L. Fróes 19897 IAN - semente); Tachigali micropetala (Ducke) Zarucchi \& Pipoly (C.S. Rosário $832 \mathrm{MG}$ - flor), (descrição de Dwyer

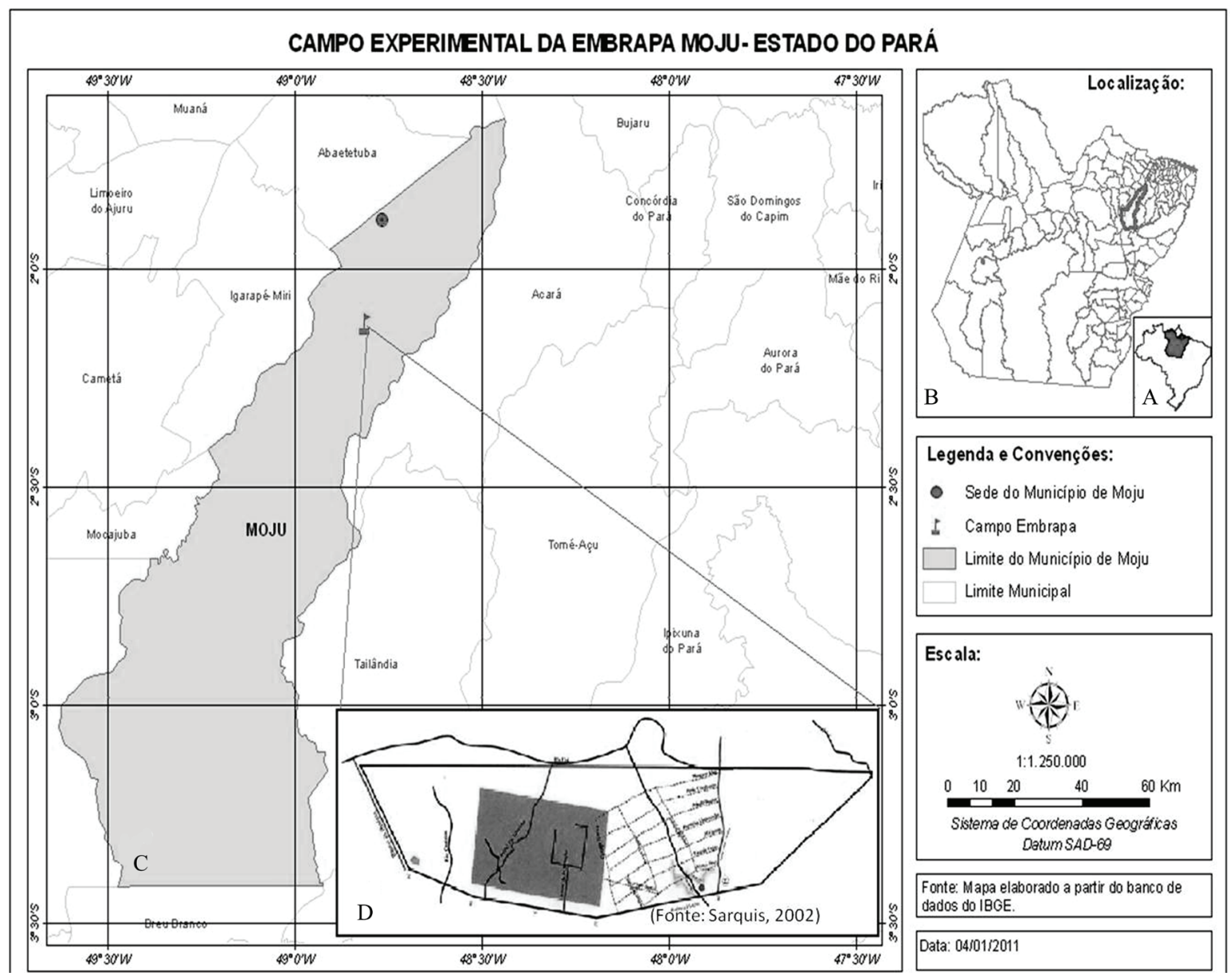

Figura 1. A. Localização do Estado do Pará no Brasil. B. Localização do município de Moju no Pará. C. Municipio de Moju. D. Planta esquemática do Campo Experimental da Embrapa Amazônia Oriental (Moju-PA) (A-C. Elaborado por Jerferson Santos; D. Fonte: Sarquis, 2002).

Figure 1. A. Location of the State of Pará in Brazil. B. Location of the municipality of Moju in the State of Pará. C. Municipality of Moju. D. Schematic delimitation of the experimental field at Embrapa Eastern Amazon (Moju-PA) (A-C. Prepared by Santos Jerferson; D. Source: Sarquis, 2002). 
(1957) - fruto); Tachigali paraensis (Huber) Barneby (A. Ducke s.n. MG16580 - semente); Tachigali vulgaris L.G. Silva \& H.C. Lima (M.S. Rodrigues \& M.P. Nascimento 371 IAN - fruto e bractéola).

\section{Resultados e Discussão}

Diversidade de Caesalpinieae ocorrentes na área de estudo - Árvores; folhas pinadas ou bipinadas (Dimorphandra e Libidibia), pecioladas; glândulas interfoliolares ausentes ou presentes (Batesia e Vouacapoua); folíolos opostos ou subopostos, margem inteira; foliólulos opostos, peciolulados, a sésseis (Dimorphandra), margem inteira. Inflorescência em panícula ou racemo; raque principal lisa ou sulcada. Flores actinomorfas ou zigomorfas, pediceladas ou sésseis (Dimorphandra); hipanto presente, raro ausente (Dimorphandra); cálice dialissépalo ou gamossépalo (Batesia, Dimorphandra e Vouacapoua), margem glabra ou ciliada (Campsiandra e Libidibia); corola dialipétala, pétalas com margem glabra ou ciliada (Campsiandra); estames 10, 5 (Dimorphandra) ou 16 (Campsiandra), estaminódios ausentes ou presentes (Dimorphandra); anteras glabras ou pilosas (Campsiandra), deiscência longitudinal; filetes pilosos ou glabros (Campsiandra, Dimorphandra e Vouacapoua); ovário piloso ou glabro (Campsiandra), estipitado, aderido à base ou à parede do hipanto; óvulos 1-9; estilete 0,5-3 cm compr.; estigma glabro ou ciliado (Batesia, Libidibia e Vouacapoua). Frutos diversos.

Chave para os representantes de Caesalpinieae do Campo Experimental da Embrapa

1. Folhas bipinadas; pecíolo 1,2-3 cm compr.

2. Folíolos 7; foliólulos 10; flores zigomorfas; estaminódios ausentes; estigma ciliado Libidibia ferrea

2. Folíolos 12-20; foliólulos 30-50; flores actinomorfas; estaminódios presentes; estigma glabro Dimorphandra macrostachya ssp. congestiflora

1. Folhas pinadas; pecíolo 3,5-11,5 cm compr.

3. Glândulas interfoliolares presentes; cálice gamossépalo; estípite ca. $0,5 \mathrm{~mm}$ compr.; estigma indumentado

4. Pecíolo e raque alados; bractéola maior ca. $5 \mathrm{~mm}$ compr., ca. 2,5 $\mathrm{mm}$ larg., cimbiforme; bractéolas menores que ca. $3 \mathrm{~mm}$ compr., ca. 1,2 mm larg., falciformes Batesia floribunda

4. Pecíolo e raque não alados; bractéola maior 2-2,5 mm compr., 1-2 mm larg., deltóide; bractéolas menores que 1,5-1,8 mm compr., 0,5-0,9 mm larg., deltóides Vouacapoua americana

3. Glândulas interfoliolares ausentes; cálice dialissépalo; estípite 1-3 mm compr.; estigma glabro.

5. Pecíolo alado; estames 16; legume com ca. $28 \mathrm{~cm}$ compr Campsiandra laurifolia

5. Pecíolo não alado; estames 10; legume criptosâmara com 6-20 cm compr.

6. Folíolos (5-)6 (-7)-8, com 11-14 cm compr., elíptico-oblongos; pétalas lineares Tachigali paraensis 6. Folíolos 14-18, com 8,9-11 cm compr, oblongos ou elípticos ou oblongo-ovalados; pétalas lineares ou obovadas

7. Raque foliar ca. 15,4 cm compr.; ovário seríceo; estípite ca. 1,5 mm compr. T. alba

7. Raque foliar 18-25,5 cm compr.; ovário hirsuto; estípite ca. $1 \mathrm{~mm}$ compr.

8. Pecíolo cilíndrico; peciólulos ca. $2 \mathrm{~mm}$ compr.; pétalas obovadas . T. micropetala

8. Pecíolo semicilíndrico ou canaliculado; peciólulos 4-7 mm compr.; pétalas lineares

9. Folíolos oblongo-ovados, ca. $10 \mathrm{~cm}$ compr.; pedicelo ca. $2 \mathrm{~mm}$ compr.; fruto ca. $6 \mathrm{~cm}$ compr. T. vulgaris

9. Folíolos oblongo-elípticos, ca. $8,9 \mathrm{~cm}$ compr.; pedicelo ca. $0,5 \mathrm{~mm}$ compr.; fruto ca. $10 \mathrm{~cm}$ compr.

T. guianensis

1. Batesia floribunda Spruce ex Benth., Trans. Linn. Soc. London 25: 303, pl. 37. 1866. Tipo: BRASIL. Amazonas: Florest of the Rio Uaupés, in North Brazil, X-1852/I-1853, Spruce 2780 (foto doholótipo $\mathrm{K}$ !, foto do isótipo RB!).

Figura 2

Árvore 20-40 m alt., DAP 30-35,7 cm. Folhas pinadas; folíolos (10-)13; estípulas precocemente caducas; pecíolo 8-9 cm compr.; raque 4,3-20,5 cm compr., ambos alados, velutinos, glândulas presentes entre os folíolos basais, podendo ocorrer entre os demais. Folíolos 10-14 cm compr., 4,5-6,4 cm larg., opostos, elíptico-oblongos, ápice cuspidado, base arredondada ou obtusa; face adaxial glabra, face abaxial velutina; peciólulos 6-7 mm compr., ca. $2 \mathrm{~mm}$ larg., rugosos, canaliculados, 

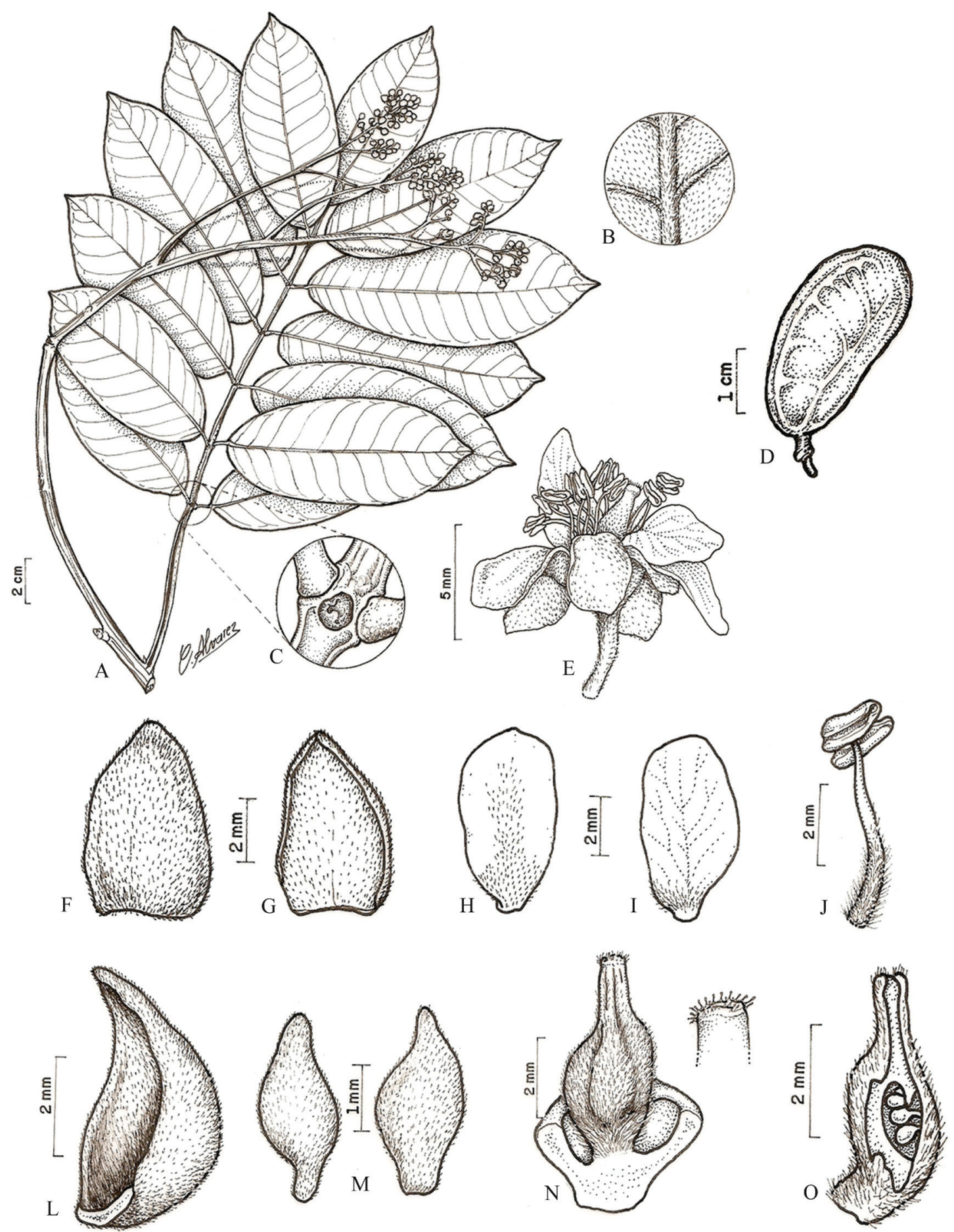

Figura 2. Batesia floribunda Spruce ex Benth. A. Ramo florido. B. Detalhe da face abaxial do folíolo, evidenciando os tricomas. C. Glândula interfoliolar. D. Fruto. E. Flor. F. Lacínia, face externa. G. Lacínia, face interna. H. Pétala, face externa. I. Pétala, face interna. J. Estame. L. Bractéola maior. M. Bractéolas menores. N. Hipanto em secção longitudinal evidenciando a inserção do gineceu. O. Ovário em secção longitudinal. (A-C, E-O. L.C. Procópio 384 (IAN); D. N.T. Silva 833(IAN)).

Figure 2. Batesia floribunda Spruce ex Benth. A. Flowring branch. B. Detail of the abaxial surface of leaves, showing the trichomes. C. Interfoliar gland. D. Fruit. E. Flower. F. Calyx lobe, external surface. G. Calyx lobe, inner surface. H. Petal, external surface. I. Petal, inner surface. J. Stamen. L. Large bracteole. M. Smaller bracteoles. N. Hypanthium in a longitudinal section showing the insertion of the gynoecium. O. Ovary on longitudinal section. (A-C, E-O. L.C. Procópio 384 (IAN); D. N.T. Silva 833 (IAN)). 
velutinos. Inflorescência em panícula; pedúnculo 1,5-2,5 cm compr.; raque 16-22 cm compr., sulcada, velutina; brácteas não vistas; bractéolas de tamanhos diferentes, externa e internamente seríceas, a maior ca. $5 \mathrm{~mm}$ compr., ca. 2,5 mm larg., cimbiforme, as duas menores ca. $3 \mathrm{~mm}$ compr., ca. 1,2 mm larg., falciformes. Flores actinomorfas; pedicelo ca. $5 \mathrm{~mm}$ compr.; hipanto 2-3 mm compr., ca. $2 \mathrm{~mm}$ diâm., velutino; cálice ca. $0,5 \mathrm{~mm}$ compr., gamossépalo, lacínias 5-6 mm compr., 3-4 mm larg., oblongas, elípticas ou ovadas, ápice arredondado, externa e internamente velutinas; corola dialipétala, pétalas ca. $6 \mathrm{~mm}$ compr., 2-3 mm larg., obovadas, externamente pubescentes no centro e na base, glabrescentes no ápice, internamente pubescentes na base; estames 10; anteras 1-2 mm compr., ca. $1 \mathrm{~mm}$ larg., glabras; filetes ca. $4 \mathrm{~mm}$ compr., dilatados da base até $2 / 3$ do compr., hirsutos; ovário 3-4,2 mm compr., 1,8-2 mm larg., pubescente; estípite ca. $0,5 \mathrm{~mm}$ compr., aderido à base do hipanto; estilete 1,3-2 mm compr.; estigma ciliado; óvulos 3. Fruto folículo, ca. 3,5 cm compr., ca. $2 \mathrm{~cm}$ larg., oblongo ou elíptico, subfalcado, sulcado, glabrescente; sementes 3, ca. $9 \mathrm{~mm}$ compr., ca. $8 \mathrm{~mm}$ larg., suborbiculares, lisas, glabras.

Material examinado: BRASIL. PARÁ: Moju, Campo Experimental da Embrapa, 5-II-2001, L.C. Procópio 384 (IAN); idem, 28-II-2002, A.M. Ferreira 168 (IAN).

Ocorre na Colômbia, Peru e Guiana Francesa (Ducke 1949, Rudas 1997, Ulibarri 2008, w3 Tropicos 2010). No Brasil, restringe-se ao domínio fitogeográfico amazônico, com distribuição geográfica para o Norte do Brasil, nos Estados do Pará, Amazonas, Acre e no Centro-Oeste, no Estado do Mato Grosso (Lima 2010a)

O gênero Batesia é assim chamado em homenagem ao viajante Henry Walter Bates, zoólogo inglês, que viajou durante 11 anos pela Amazônia (Ulibarri 2008). O gênero é monoespecífico e foi, inicialmente, identificado na exsicata como Tachigali erythrosperma, por Spruce em 1852, estudando amostra botânica da floresta à margem do rio Uaupés, no Norte do Brasil. Entretanto, Spruce (1865) reconheceu que esse material não pertencia ao gênero Tachigali e descreveu Batesia; a espécie B. floribunda foi estabelecida por Bentham (1866).

Ducke (1949) comentou que B. floribunda é uma árvore grande de folhagem escura e bonito porte, parecida com Vouacapoua americana
Aubl., porém atinge dimensões maiores, tem flor amarelo-pálida, semente vermelha, brilhante, madeira nova pardacento-clara, ficando mais tarde pardo-avermelhado-clara, pouco macia e mais leve que o acapu verdadeiro, fácil de trabalhar, de textura fina, que poderia ser utilizada na marcenaria.

Batesiafloribunda é uma espécie muito confundida com Ormosia. Nos herbários IAN, INPA e MG, foram encontrados espécimes de $B$. floribunda identificados como Ormosia, apenas em nível de gênero. A principal diferença entre esses dois gêneros é que Batesia apresenta pecíolos alados e glândulas interfoliolares, enquanto Ormosia possui pecíolo cilíndrico e sem glândulas. Batesia floribunda destaca-se por ser a única espécie dentre as leguminosas amazônicas a possuir células oleíferas associadas ao parênquima axial do xilema secundário (Gomes, dados não publicados). É importante ressaltar que a madeira das espécies de Ormosia não apresenta essa característica.

$\mathrm{Na}$ diagnose do gênero, Spruce (1865) caracterizou-o pelas folhas imparipinadas, caráter reafirmado por Macbride (1943), Rudas (1997) e Ulibarri (2008). Entretanto, na área de estudo foram coletados ramos com folhas imparipinadas ou paripinadas e ramos contendo folhas pari e imparipinadas. Bentham (1866) descreveu as folhas da espécie como apresentando 11 folíolos, no entanto, nos trabalhos acima mencionados são referidos 9 a 13 pares de folíolos. Na área de estudo, o material apresentou 10 a 13 folíolos e no material de outras áreas foram observados exemplares com 9 a 13 folíolos.

Essa espécie assemelha-se a Vouacapoua americana por apresentar três bractéolas, glândulas interfoliolares, cálice gamossépalo, corola dialipétala e estigma com tricomas. Porém $B$. floribunda diferencia-se pelos folíolos elíptico-oblongos e em número de (10-)13, pecíolo alado e fruto do tipo folículo, enquanto que em $V$. americana, os folíolos são ovado-elípticos, em número de 7-11, o pecíolo é destituído de ala e o fruto é do tipo legume.

2. Campsiandra laurifolia Benth., J. Bot. (Hooker) 2(10): 94. 1840. Tipo: BRASIL. Amazonas: Rio Negro, 1837, Riedel 83 (foto do holótipo K!).

Figura 3

Árvore ca. $6 \mathrm{~m}$ alt., DAP ca. $15 \mathrm{~cm}$. Folhas pinadas; folíolos 11; estípulas precocemente caducas; pecíolo ca. $3,5 \mathrm{~cm}$ compr.; raque ca. $8,1 \mathrm{~cm}$ compr., ambos alados e seríceos. Folíolos ca. 8,4 cm compr., ca. $3 \mathrm{~cm}$ larg., 


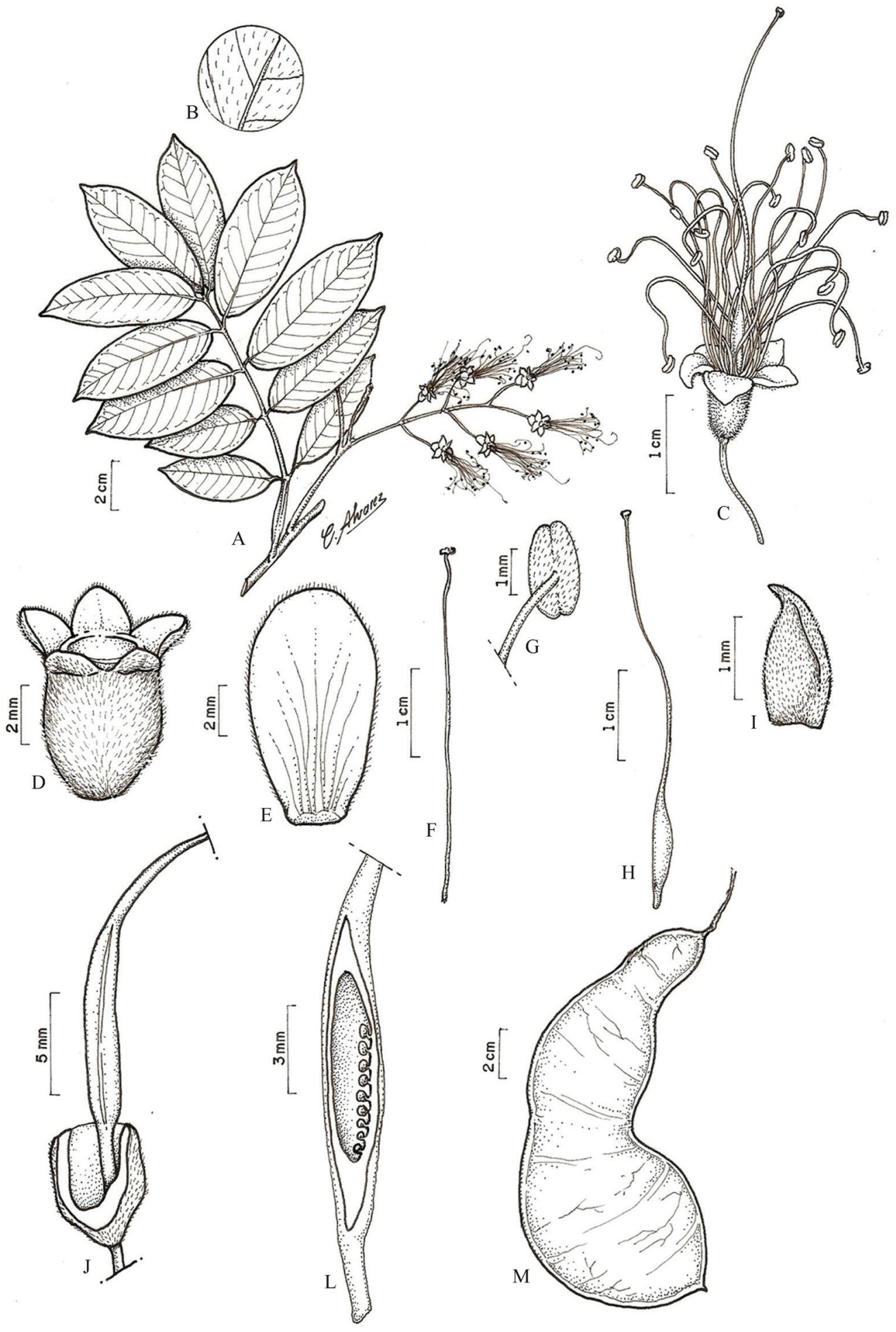

Figura 3. Campsiandra laurifolia Benth. A. Ramo florido. B. Detalhe das faces adaxial e abaxial do folíolo, evidenciando os tricomas. C. Flor. D. Cálice e hipanto. E. Pétala. F. Estame. G. Detalhe da antera, evidenciando tricomas. H. Gineceu. I. Bractéola. J. Hipanto em secção longitudinal evidenciando a inserção do gineceu. L. Ovário em secção longitudinal. M. Fruto. (A-L. M.S. Rodrigues 395 (IAN); G.C. Ferreira \& J.C. Freitas 588 (IAN)).

Figure 3. Campsiandra laurifolia Benth. A. Branch with inflorescence. B. Detail of the adaxial and abaxial leaflet surface, showing the trichomes. C. Flower. D. Calyx and hypanthium. E. Petal. F. Stamen. G. Detail of anther, showing trichomes. H. Gynoecium. I. Bracteole. J. Hypanthium in a longitudinal section showing the insertion of the gynoecium. L. Ovary in longitudinal section. M. Fruit. (A-L. M.S. Rodrigues 395 (IAN); G.C. Ferreira \& J.C. Freitas 588 (IAN)). 
opostos ou subopostos, oblongos, ápice cuspidado, base oblíqua; faces adaxial e abaxial pubescentes; peciólulos ca. 1,2 mm compr., ca. $1 \mathrm{~mm}$ larg., rugosos, levemente canaliculados, pilosos. Inflorescência em panícula; pedúnculo ca. $2 \mathrm{~cm}$ compr.; raque ca. $8,5 \mathrm{~cm}$ compr., levemente sulcada, serícea; brácteas não vistas; bractéolas ca. $2 \mathrm{~mm}$ compr., ca. $1 \mathrm{~mm}$ larg., deltóides, externamente seríceas, internamente glabras. Flores actinormorfas; pedicelo 1,2-2,2 cm compr.; hipanto ca. $5 \mathrm{~mm}$ compr., ca. 4,5 mm diâm., piloso; cálice dialissépalo, sépalas ca. $2 \mathrm{~mm}$ compr., ca. $2 \mathrm{~mm}$ larg., deltóides, externamente seríceas, ápice arredondado a obtuso, margem ciliada; corola dialipétala, pétalas ca. $9 \mathrm{~mm}$ compr., ca. $6 \mathrm{~mm}$ larg., obovadas, externa e internamente glabras, margem ciliada; estames 16; anteras ca. $2 \mathrm{~mm}$ compr., ca. 0,9 $\mathrm{mm}$ larg., face dorsal pilosa; filetes ca. $4 \mathrm{~cm}$ compr., glabros; ovário ca. $8 \mathrm{~mm}$ compr., ca. 1,5 mm larg., glabro; estípite ca. $3 \mathrm{~mm}$ compr., aderido à parede do hipanto; estilete ca. $3 \mathrm{~cm}$ compr., glabro; estigma glabro, dilatado; óvulos 9. Fruto legume, ca. $28 \mathrm{~cm}$ compr., ca. $8 \mathrm{~cm}$ larg., oblongo-falcado, plano, liso, glabro; sementes 4, ca. $9 \mathrm{~mm}$ compr., ca. $8 \mathrm{~mm}$ larg., aladas, orbiculares, lisas, glabras.

Material examinado: BRASIL. PARÁ: Moju, Campo Experimental da Embrapa, 10-I-2000, G.C. Ferreira \& J.C. Freitas 588 (IAN).

Espécie com distribuição no Brasil, Venezuela, Colômbia, Guiana e Peru (Ulibarri 2008, w3 Tropicos 2010). No Brasil, ocorre nos Estados do Pará, Amapá, Roraima, Amazonas e Rondônia (Ducke 1949, Lima 2010b). De acordo com Ducke (1949), a espécie é comum nas margens de todos os rios e lagos, principalmente daqueles cujas águas não sejam excessivamente turvas.

Bentham (1840) comentou que havia recebido uma amostra coletada no rio Negro com o nome de Inga laurifolia; após analisar esse material, verificou que o mesmo era muito parecido com Campsiandra comosa, da qual diferia pelo número, forma e consistência dos folíolos, bem como pelo número de nervuras secundárias e tamanho das flores, e o descreveu como C. laurifolia.

Macbride (1943) comentou que C. laurifolia é parecida com $C$. angustifolia, e que $C$. rosea é sinônimo de C. laurifolia.

Cowan (1953), estudando o gênero Campsiandra, reduziu $C$. laurifolia a uma variedade de $C$. comosa. Desde 1953, o gênero permaneceu em relativa obscuridade, enquanto isso, as coleções foram se acumulando através de várias expedições botânicas nos países da Bacia Amazônica, principalmente no Brasil; dessa forma, a maioria desses espécimes permaneceu incorretamente ou mal identificado (Stergios 1996). Na revisão desse gênero, realizado por Stergios (1996), C. laurifolia foi restabelecida; esse autor comentou, ainda, que Cowan examinou um número limitado de espécimes de herbário e não analisou os tipos.

Barneby et al. (1999), estudando o tipo de C. laurifolia, esclareceram que essa espécie é bem distinta de C. comosa, visto que essa última apresenta folíolos elíptico-oblongos e visivelmente coriáceos e glabros, podendo apresentar alguns tricomas espalhados na superfície inferior, perto da base dos foliolos, e as flores são maiores que as de C. laurifolia; o tubo do cálice e sépalas de C. comosa são glabros, ao invés de densamente puberulentos como em C. laurifolia. Esses autores comentaram, ainda, que C. comosa é endêmica da Guiana e do Suriname.

Mesmo com os trabalhos recentes de Stergios (1996) e Barneby et al. (1999), aceitando C. laurifolia como espécie válida, muitos estudiosos ainda a consideram como uma variedade de C. comosa. É importante ressaltar que no trabalho de Barneby et al. (1999), um dos colaboradores é Cowan, o autor que reduziu $C$. laurifolia a variedade de $C$. comosa.

No presente trabalho, adotou-se Campsiandra laurifolia de acordo com Stergios (1996) e Barneby et al. (1999), devido ao fato das amostras analisadas apresentarem folíolos oblongos e pubescentes em ambas as faces, e hipanto e cálice com tricomas, concordando com os caracteres utilizados por esses autores.

Campsiandra laurifolia é facilmente reconhecida pelos pecíolos alados, frutos grandes (ca. $28 \mathrm{~cm}$ compr.) e planos, flores com 16 estames, filetes com $4 \mathrm{~cm}$ compr. e gineceu com 5,2 cm compr. A outra espécie da tribo, na área, que apresenta pecíolo alado é Batesia floribunda, entretanto, difere de C. laurifolia pelos caracteres mencionados no início deste parágrafo.

3. Dimorphandra macrostachya Benth. ssp. congestiflora (Sprague \& Sandwith) M.F. Silva, F1. Neotrop. 44: 106. $1986 \equiv$ Dimorphandra congestiflora Sprague \& Sandwith, Bull. Misc. Inform. Kew (8): 395-406. 1932. Tipo: BRITISH GUIANA. MazarunI: "Mazaruni River, Macreba Falls, Kurupung River", VII-1925, Alston 348 (foto do holótipo K!, foto do isótipo RB!); Potaro River, Waratuk Path, XI-1898, Jenman 7429 (parátipo NY). Figura 4 


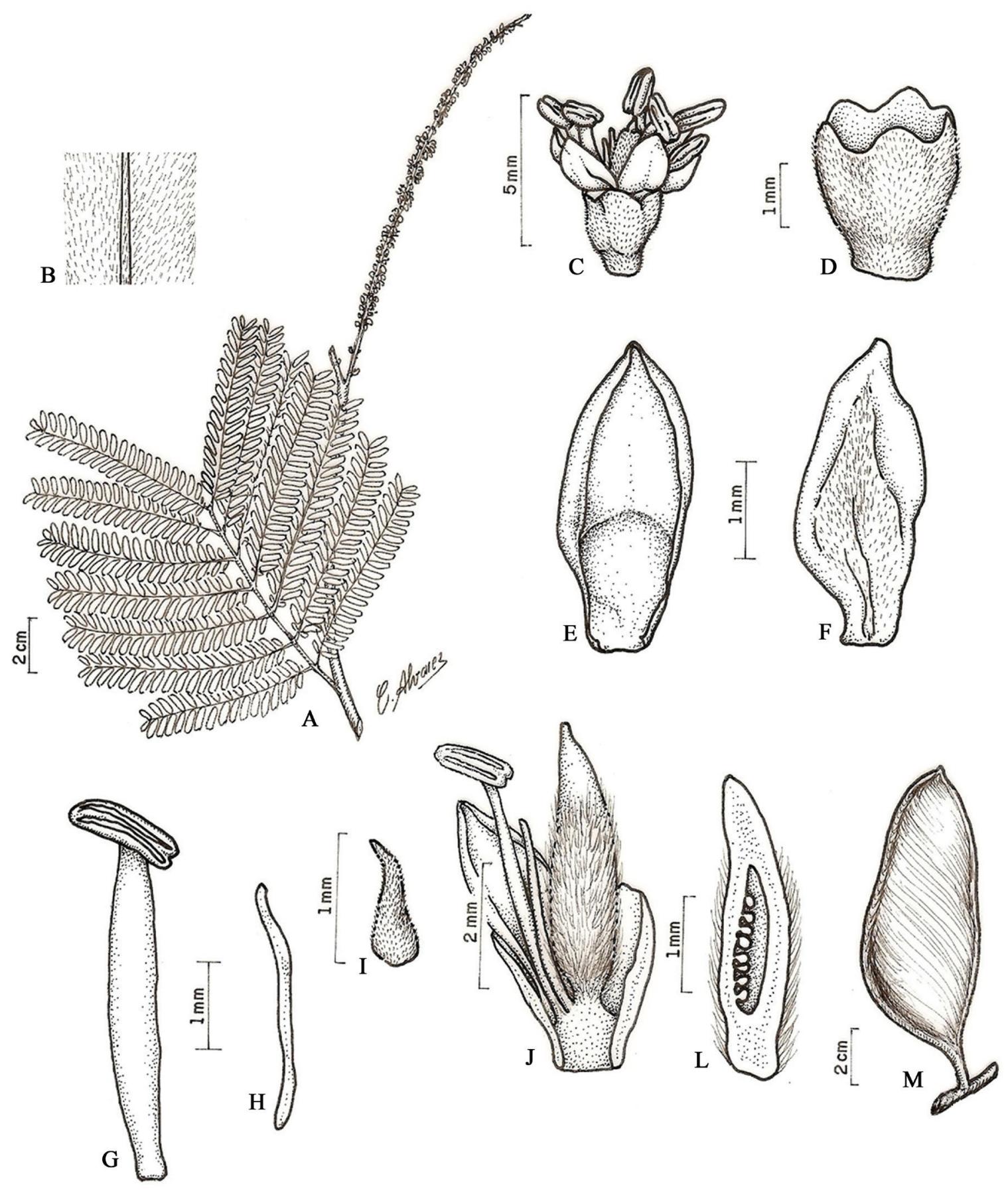

Figura 4. Dimorphandra macrostachya Benth. ssp. congestiflora (Sprague \& Sandwith) M. F. Silva. A. Ramo florido. B. Detalhe da face abaxial do folíolo, evidenciando os tricomas. C. Flor. D. Cálice. E. Pétala, face interna. F. Pétala, face externa. G. Estame. H. Estaminódio. I. Bractéola. J. Hipanto em secção longitudinal evidenciando a inserção do gineceu. L. Ovário em secção longitudinal. M. Fruto. (A-L. M.S. Rodrigues 393 (IAN); M.L.C. Procópio 443 (IAN)).

Figure 4. Dimorphandra macrostachya Benth. ssp. congestiflora (Sprague \& Sandwith) M. F. Silva. A. Branch with inflorescence. B. Detail of the abaxial surface of leaves, showing the trichomes. C. Flower. D. Calyx. E. Petal, inner surface. F. Petal, external surface. G. Stamen. H. Staminodes. I. Bracteole. J. Hypanthium in a longitudinal section showing the insertion of the gynoecium. L. Ovary in longitudinal section. M. Fruit. (A-L. M.S. Rodrigues 393 (IAN); M.L.C. Procópio 443 (IAN)). 
Árvore 12-15 m alt., DAP 30-37,5 cm. Folhas bipinadas; 12-20 folíolos; estípulas precocemente caducas; pecíolo 1,2-2,5 cm compr., cilíndrico ou semicilíndrico, pubescente; raque 5,5-22,5 cm compr., cilíndrica ou trígona, levemente sulcada, pubescente. Folíolos 8,6-14,9 cm compr., 3,2-4,5 cm larg., opostos; peciólulos 4-7 mm compr., rugosos, canaliculados, pubescentes. Foliólulos 30-50, 1,8-2,5 cm compr., 5-8 mm larg., sésseis, opostos, oblongos ou obovados, ápice retuso ou arredondado, base assimétrica; face adaxial glabra, face abaxial serícea. Inflorescência racemo-espiciforme; pedúnculo 1,1-2 cm compr.; raque 6,5-28 cm compr., não sulcada, velutina; brácteas não vistas; bractéolas $0,5-1 \mathrm{~mm}$ compr., deltóides, externamente seríceas. Flores actinormorfas, sésseis; cálice ca. 2,5 mm compr., gamossépalo, lobos 0,5-1 mm compr., ca. $1 \mathrm{~mm}$ larg., deltóides, ápice obtuso, externa e internamente pubescentes; corola dialipétala, pétalas ca. $3 \mathrm{~mm}$ compr., ca. $1,5 \mathrm{~mm}$ larg., obovadas a cimbiformes, externamente pilosas na parte central, internamente pilosas ou glabras no centro; estames 5, estaminódios 5, filiformes, glabros; anteras 1,3-1,5 mm compr., ca. 0,5 mm larg., glabras; filetes ca. $4 \mathrm{~mm}$ compr., glabros; ovário 2,5-3 mm compr., ca. $1 \mathrm{~mm}$ larg., hirsuto, brevemente estipitado, aderido à base do hipanto; estilete curto, ca. $0,5 \mathrm{~mm}$ compr., glabro; estigma glabro; óvulos 7-9. Fruto legume nucóide, 11-17 cm compr., 5,6-8 cm larg., oblongóide a ovóide com base assimétrica, plano, levemente sulcado, incano, com sutura ventral larga e dorsal apenas espessada; sementes 4-9, 1,2-2,5 mm compr., 6-7 mm larg., obovadas, lisas, glabras.

Material examinado: BRASIL. PARÁ: Moju, Campo Experimental da Embrapa, 10-II-1998, G.C. Ferreira 400 (IAN); idem, 20-V-199, G.C. Ferreira 463 (IAN); idem, 1-VII-2003, M.P. Nascimento 226 (IAN); idem, 20-II-2001, L.C. Procópio 415 (IAN); idem, 26-II-2002, L.C. Procópio 448 (IAN); idem, 24-II-2002, L.C. Procópio 443 (IAN); idem, 16-II-2010, M.S. Rodrigues 382 (IAN); idem, 27-III-2003, N.A.S Carmo 09 (IAN); idem, 19-VIII-2010, M.S. Rodrigues 393 (IAN); Campo Experimental da Embrapa, 20-VIII-2010, M.S. Rodrigues 394 (IAN).

É a primeira referência da epécie para o Brasil. Silva (1986) considerou Dimorphandra macrostachya ssp. congestiflora como restrita à região da Guiana, em altitudes que variam de 220 até $810 \mathrm{~m}$, ao longo da margens de rios em solos arenosos de savana.

Irwin (1966) comentou que Ducke, em 1935, propôs Dimorphandra glabrifolia para acomodar uma variante menor da Amazônia, que difere de D. congestiflora apenas na redução da pubescência, especialmente na superfície inferior dos foliólulos; o autor considerou que esse caráter não justificaria a manutenção de dois táxons distintos e propôs a sinonimização de $D$. glabrifolia.

Silva (1986) reduziu $D$. glabrifolia e $D$. congestiflora a duas subespécies, respectivamente, D. macrostachya ssp. glabrifolia e D. macrostachya ssp. congestiflora. Essa autora diferenciou as subespécies com base no número e indumento dos folíolos, tamanho do pedicelo e forma do cálice. Barneby et al. (1999) mencionaram que essas subespécies nem sempre são bem diferenciadas, mas aceitaram-nas.

O material da área de estudo foi identificado como D. macrostachya ssp. congestiflora, de acordo com a chave de identificação proposta por Silva (1986), por apresentar folhas com até 10 pares de pinas, foliólulos com a face abaxial seríceo-pubescente e flores sésseis; entretanto, a coloração dourada dos tricomas na superficie dos foliólulos, que a referida autora comentou, não foi observada de forma homogênea nos exemplares aqui estudados.

Dimorphandra macrostachya ssp. congestiflora e Libidibia ferrea são os únicos táxons entre os estudados que apresentavam folhas bipinadas. A primeira diferencia-se por apresentar maior número de folíolos (12-20) e foliólulos (30-50), indumento seríceo na superfície abaxial, flores actinomorfas, estaminódios e, principalmente, pelo tipo do fruto, que é um legume nucóide.

4. Libidibia ferrea (Mart. ex Tul.) L.P. Queiroz, Legum. Caatinga: 130. $2009 \equiv$ Caesalpinia ferrea Mart. ex Tul.,Arch. Mus. Hist. Nat. Paris 4: 137. 1844. Tipo: BRASIL. BAHIA: Prov. Bahiensem Brasiliae borealis, Martius s.n. (síntipo não localizado). BRASIL. Alagoas: crescit etiam in ejusdem regionis prov. Alagoas, 1838, Gardner 1277 (foto do síntipo $\mathrm{K} !)$.

Figura 5

Árvore ca. $7 \mathrm{~m}$ alt. Folhas bipinadas; folíolos 7; estípulas precocemente caducas; pecíolo ca. $3 \mathrm{~cm}$ compr.; raque ca. 9,5 cm compr., ambos cilíndricos, glabros. Folíolos ca. $8 \mathrm{~cm}$ compr., ca. $6 \mathrm{~cm}$ larg., opostos ou subopostos; peciólulos ca. 1,5 cm compr., rugosos, cilíndricos, glabros. Foliólulos 10, ca. $3,2 \mathrm{~cm}$ compr., ca. 1,4 cm larg., opostos, elípticos, ápice retuso, base oblíqua; faces adaxial e abaxial glabras. Inflorescência em panícula terminal; pedúnculo ca. $1,1 \mathrm{~cm}$ compr.; raque ca. $8,5 \mathrm{~cm}$ compr., glabra, 


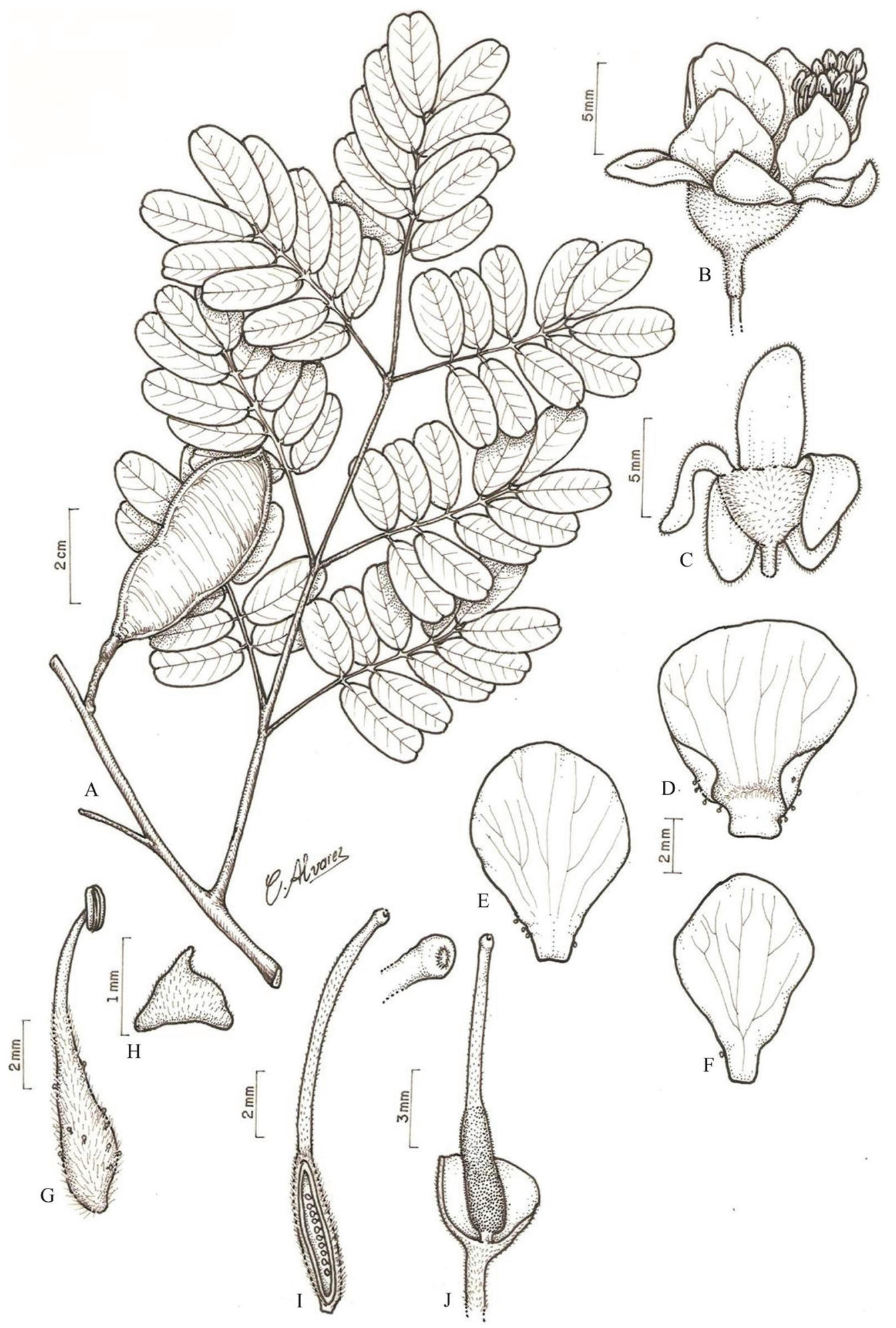

Figura 5. Libidibia ferrea (Mart. ex Tul.) L.P. Queiroz. A. Ramo frutificado. B. Flor. C. Cálice. D. Vexilo. E. Asa. F. Carena. G. Estame. H. Bractéola. I. Ovário em secção longitudinal. J. Hipanto em secção longitudinal evidenciando a inserção do gineceu. (A.B. G.S. Ribeiro 2362 (IAN); B-J. M.S. Rodrigues \& J.C.L. Oliveira 379 (IAN)).

Figure 5. Libidibia ferrea (Mart. ex Tul.) L.P. Queiroz. A. Branch with fruit. B. Flower. C. Calyx. D. Standard. E. Wing. F. Keel. G. Stamen. H. Bracteole. I. Ovary in longitudinal section. J. Hypanthium in a longitudinal section showing the insertion of the gynoecium. (A.B.G.S. Ribeiro 2362 (IAN); B-J. M.S. Rodrigues \& J.C.L. Oliveira 379 (IAN)). 
lenticelada; brácteas não vistas; bractéolas ca. $0,9 \mathrm{~mm}$ compr., ca. $1 \mathrm{~mm}$ larg., deltóides, externamente pubescentes. Flores zigomorfas; pedicelo ca. $1 \mathrm{~cm}$ compr.; hipanto ca. $5 \mathrm{~mm}$ compr., ca. 5,5 mm diâm., pubescente; cálice dialissépalo, sépalas ca. $7 \mathrm{~mm}$ compr., ca. $4 \mathrm{~mm}$ larg., oblongas, ápice arredondado, externa e internamente glabras, margem ciliada; corola dialipétala, vexilo ca. $8 \mathrm{~mm}$ compr., $7 \mathrm{~mm}$ larg., com tricomas na base da face ventral, glândulas na base, asas obovadas, ca. $8 \mathrm{~mm}$ compr., ca. $6 \mathrm{~mm}$ larg., glândulas na base, externa e internamente glabras, carenas obovadas, ca. $6 \mathrm{~mm}$ compr., ca. 4,5 mm larg., glândulas na base, externa e internamente glabras; estames 10; anteras ca. $1 \mathrm{~mm}$ compr., ca. $0,8 \mathrm{~mm}$ larg., glabras; filetes ca. $9 \mathrm{~mm}$ compr., dilatados, pubescentes da base até $2 / 3$ do compr., glândulas estipitadas ocorrendo muitas vezes até $2 / 3$ da base; ovário ca. $5 \mathrm{~mm}$ compr., ca. 1,3 mm larg., velutino; estípite curto, ca. $0,5 \mathrm{~mm}$ compr., aderido à base do hipanto; estilete ca. $7 \mathrm{~mm}$ compr., pubescente, tornando-se glabro para o ápice; estigma ciliado; óvulos 9. Fruto legume bacóide, ca. 5,5 cm compr., ca. $2 \mathrm{~cm}$ larg., oblongo, liso, glabro; sementes 6, ca. $8 \mathrm{~mm}$ compr., ca. $5 \mathrm{~mm}$ larg., elípticas, lisas, glabras.

Material examinado: BRASIL. PARÁ: Moju, Campo Experimental da Embrapa, 7-VI-1996, B.G.S. Ribeiro 2362 (IAN).

A espécie é encontrada nos Estados do Amazonas (Ulibarri 1996) e Pará (Freitas 2009). Ocorre em todo o Nordeste e Sudeste (com exceção de São Paulo), no Centro-Oeste há registro apenas para o Mato Grosso do Sul (Queiroz 2009, Lewis 2010).

Libidibia ferrea foi designada por Martius (1828) como Caesalpinia ferrea, entretanto só foi descrita por Tulasne (1844). Baillon (1876) transferiu essa espécie para o gênero Apuleia. Libidibia foi segregado de Caesalpinia por Lewis et al. (2005). Queiroz (2009) subordinou Caesalpinia ferrea e suas respectivas variedades ao gênero Libidibia, mencionando que essa espécie pertence a um grupo de espécies muito semelhantes, que se distribui principalmente em florestas secas neotropicais e apresenta variação extremamente complexa e difícil de interpretar, com muitos intermediários entre ela e outras afins.

Libidibia ferrea e Dimorphandra macrostachya ssp. congestiflora foram as únicas espécies registradas neste estudo com folhas bipinadas. A primeira diferencia-se por apresentar menor número de folíolos (7) e foliólulos (10), folhas glabras em ambas as faces, flores zigomorfas, ausência de estaminódios, sendo o único táxon dentre os estudados, que possui legume bacóide. Por sua vez, D. macrostachya ssp. congestiflora apresenta maior número de folíolos (12-20) e foliólulos (30-50), com indumento seríceo na superfície abaxial, flores actinomorfas, estaminódios presentes e fruto legume nucóide.

\section{Tachigali Aubl.}

Árvores. Folhas pinadas; folílolos (5-)6(-7)-18, opostos; peciólulos 2-7 cm de compr., 1-2 mm de larg., ápice acuminado ou cuspidado, base oblíqua. Inflorescência em panícula terminal. Flores actinomorfas ou ligeiramente zigomorfas; cálice dialissépalo; corola dialipétala, pétalas lineares ou obovadas; estames 10, anteras glabras, filetes hirsutos; ovário hirsuto ou seríceo, estípite aderido à base ou à parede do hipanto; estigma glabro. Fruto criptossâmara.

5. Tachigali alba Ducke, Arch. Jard. Bot. Rio de Janeiro 3: 92. 1922. Tipos: BRASIL. PARÁ: Prope Gurupá, 20-VIII-1918, A. Ducke s.n. (lectótipo MG17227! - designado por Van der Werff 2008); habitat in silvis pimariis non inundatis in regione cataractarum inferiorum fluvii prope Tapajoz, 26-VI-1918,A.Duckes.n. (síntipo MG17075!,foto do isosíntipoRB10980!,foto doisosíntipoUS1442409!); prope Obidos, 15-VII-1918, A. Ducke s.n. (síntipo MG17110!, foto do isosíntipo RB10979!).

Figura 6

Árvore ca. $15 \mathrm{~m}$ alt., DAP ca. $46 \mathrm{~cm}$. Folíolos 14; estípulas não vistas; pecíolo ca. $5 \mathrm{~cm}$ compr., glabrescente; raque ca. 15,4 cm compr., canaliculada, glabrescente. Folíolos ca. $10 \mathrm{~cm}$ compr., ca. $4 \mathrm{~cm}$ larg., oblongo-ovados, ápice acuminado; face adaxial glabra, às vezes com base glabrescente, face abaxial pubescente; peciólulos ca. $6 \mathrm{~mm}$ compr., ca. $2 \mathrm{~mm}$ larg., rugosos, cilíndricos, glabrescentes. Inflorescência com pedúnculo ca. 4,5 cm compr.; raque ca. $12 \mathrm{~cm}$ compr., sulcada, serícea; brácteas não vistas; bractéolas ca. $5 \mathrm{~mm}$ compr., subuladas, externa e internamente seríceas. Flores actinomorfas; pedicelo ca. $3 \mathrm{~mm}$ compr.; hipanto assimétrico, 2-3 mm compr., ca. $3 \mathrm{~mm}$ diâm., seríceo; sépalas ca. $4 \mathrm{~mm}$ compr., ca. $3 \mathrm{~mm}$ larg., cimbiformes, seríceas em ambas as faces, às vezes glabrescentes no ápice da face interna; pétalas ca. $5 \mathrm{~mm}$ compr., ca. $2 \mathrm{~mm}$ larg., obovadas, externamente glabras, internamente hirsutas na região central da base até 3/4; anteras ca. 2 mm compr., ca. 


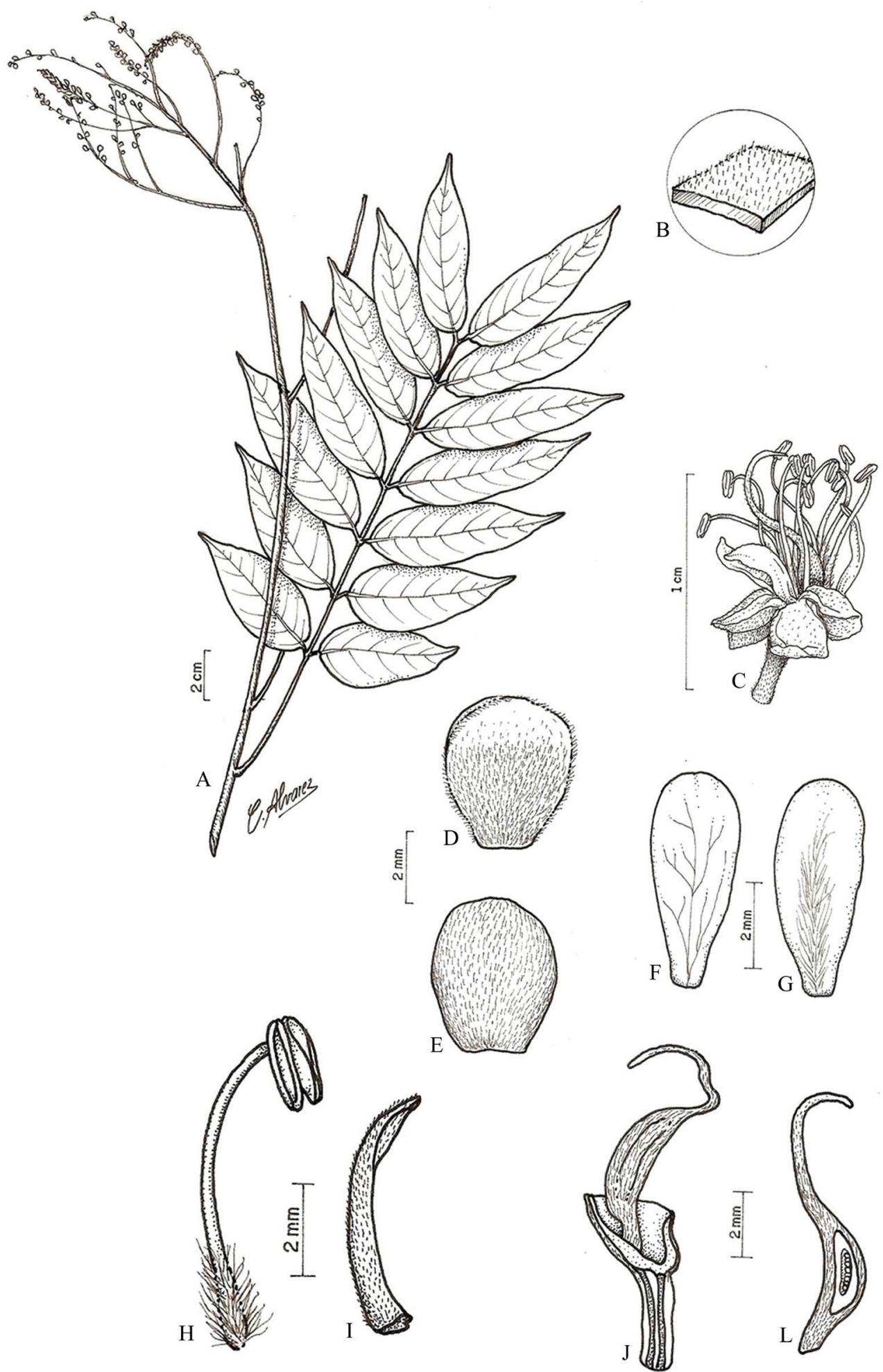

Figura 6. Tachigali alba Ducke. A. Ramo florido. B. Detalhe da face abaxial do folíolo, evidenciando os tricomas. C. Flor. D. Sépala, face interna. E. Sépala, face externa. F. Pétala, face externa. G. Pétala, face interna. H. Estame. I. Bractéola. J. Hipanto em secção longitudinal evidenciando a inserção do gineceu. L. ovário em secção longitudinal. (A-B, I. J.C.L. Oliveira 428 (IAN); C-H, J e L. N.T. Silva 955 (IAN)).

Figure 6. Tachigali alba Ducke. A. Branch with inflorescence. B. Detail of the abaxial surface of leaves, showing the trichomes. C. Flower. D. Sepals, inner surface. E. Sepals, external surface. F. Petal, external surface. G. Petal, inner surface. H. Stamen. I. Bracteole. J. Hypanthium in a longitudinal section showing the insertion of the gynoecium. L. Ovary in longitudinal section. (A-B, I. J.C.L. Oliveira 428 (IAN); C-H, J and L. N.T. Silva 955 (IAN)). 
$1 \mathrm{~mm}$ larg., glabras; filetes ca. $7 \mathrm{~mm}$ compr., hirsutos da base até $1 / 4$ do compr.; ovário ca. $5 \mathrm{~mm}$ compr., ca. 1,8 mm larg., seríceo; estípite ca. 1,5 mm compr., aderido à parede do hipanto; estilete ca. $6 \mathrm{~mm}$ compr., seríceo na base; óvulos 8. Fruto ca. $12 \mathrm{~cm}$ compr., $5 \mathrm{~cm}$ larg., oblongo; sementes não vistas.

Material examinado: BRASIL. PARÁ: Moju, Campo Experimental da Embrapa, 22-IV-2004, J.C.L. Oliveira 428 (IAN).

Segundo Lima (2010c) Tachigali alba é endêmica do Brasil, pertencendo ao domínio fitogeográfico Amazônico, onde, segundo Ducke (1949), Dwyer (1954) e Silva et al. (1989), ocorre nos Estados do Acre, Maranhão, Pará, Amapá e Amazonas.

Tachigali alba foi descrita por Ducke (1922), que a considerou próxima de T. paniculata. Dwyer (1954) reduziu-a a variedade de Tachigali paniculata, alegando que apesar das flores desta espécie possuir em um pequeno receptáculo, apresentam os demais caracteres iguais aos de $T$. paniculata, incluindo a coloração das flores variando de branco a amarelo.

No presente trabalho, constatou-se que Tachigali alba difere de T. paniculata, também por apresentar pecíolo semicilíndrico e raque canaliculada em vez de trígona. Silva et al. (1989) consideraram T. alba como uma variedade de T. paniculata; entretanto, Van der Werff (2008) e Lima (2010c) aceitaram-na como espécie distinta. Van der Werff (2008) considerou $T$. alba muito próxima de $T$. richardiana, diferindo apenas pelos estames dimórficos presentes em T. richardiana e pelo número de nervuras secundárias (8-10 em T. alba vs. 4-7 em T. richardiana), além da presença de tricomas na face externa das pétalas de T. richardiana, enquanto que, em T. alba, tal estrurura apresenta-se glabra. Tachigali alba diferencia-se das demais espécies congenéricas estudadas, pelos folíolos oblongo-ovados, pedicelo com ca. $3 \mathrm{~mm}$ compr., ovário com ca. $5 \mathrm{~mm}$ compr. e estilete com $6 \mathrm{~mm}$ compr.

6. Tachigali guianensis (Benth.) Zarucchi \& Herend., Monogr. Syst. Botany Missouri Bot. Gard. 45: 1254. 1993 三 Sclerolobium guianense Benth., Hooker's J. Bot. Kew Gard. Misc. 2: 237. 1850. Tipos: BRITISH GUIANA. 1845, Rob. Schomburgk, 2nd Coll. 598 (foto do lectótipo K!-designado por Zarucchi \& Herendeen 1993, foto do isolectótipo NY!); Rich. Schomburgk 931 (tipo não localizado); FRENCH GUIANA. CAYENNE, Martin s.n. (sintipo K!). Figura 7

Árvore ca. 12 m alt. Folíolos 14-18, estípulas ca. $5 \mathrm{~mm}$ compr., opostas, fimbriadas, pubescentes; pecíolo ca. 4,5 cm compr.; raque ca. $18 \mathrm{~cm}$ compr., ambos canaliculados, glabrescentes. Folíolos ca. $8,9 \mathrm{~cm}$ compr, ca. 3,1 cm larg., oblongo-elípticos, ápice acuminado; face adaxial glabra, face abaxial glabrescente; peciólulos ca. $4 \mathrm{~mm}$ compr., ca. 1,1 mm larg., levemente rugosos, semicilíndricos, glabrescentes. Inflorescência com pedúnculo ca. $4 \mathrm{~cm}$ compr.; raque ca. $16 \mathrm{~cm}$ compr., sulcada, pubescente; brácteas ca. $5 \mathrm{~mm}$ compr., fimbriadas, pubescentes; bractéolas ca. $3 \mathrm{~mm}$ compr., subuladas, externa e internamente pubescentes. Flores actinomorfas; pedicelo ca. $0,5 \mathrm{~mm}$ compr.; hipanto ca. $1,5 \mathrm{~mm}$ compr., ca. 1,2 mm diâm., seríceo; sépalas ca. $2 \mathrm{~mm}$ compr., ca. 1,5 mm larg., cimbiformes, seríceas em ambas as faces; corola dialipétala, pétalas ca. 1,2 mm compr., lineares, glabras; anteras ca. $1 \mathrm{~mm}$ compr., ca. $0,5 \mathrm{~mm}$ larg.; filetes ca. $5 \mathrm{~mm}$ compr., hirsutos da base até $2 / 5$ do compr.; ovário ca. $2 \mathrm{~mm}$ compr., ca. $1 \mathrm{~mm}$ larg., hirsuto; estípite ca. $1 \mathrm{~mm}$ compr., aderido à base do hipanto; estilete ca. 2,5 mm compr., glabro; óvulos não vistos. Fruto ca. $10 \mathrm{~cm}$ compr., ca. 2,3 cm larg., oblongo, liso, glabro; semente 1, ca. 1,2 cm compr., ca. $5 \mathrm{~mm}$ larg., oblonga, lisa, glabra.

Material examinado: BRASIL. PARÁ: Moju, Campo Experimental da Embrapa, 4-VII-1997, G.C. Ferreira 120 (IAN).

Espécie com distribuição principal na porção setentrional sulamericana (Brasil, Guiana Francesa, Suriname, Guiana, Venezuela, Colômbia, Equador e Peru) (Dwyer 1957, Killeen et al. 1993). No Brasil, é registrada para os Estados do Pará, Amapá, Acre, Amazonas, Rondônia e Bahia conforme Dwyer (1957), Lewis (1987), Silva et al. (1989) e Lima (2010c).

Bentham (1850) descreveu T. guianensis baseado nas coleções de Rob. Schomburg 598 e Rich. Schomburg 931. Durante o presente trabalho, localizou-se apenas o material de Rob. Schomburg, 598. Bentham (1850) mencionou na descrição, que $S$. guianense (T. guianensis) é muito próxima de $S$. tinctorium Benth. (T. tinctoria (Benth.) Zarucchi \& Herend.) mas os folíolos são menores, mais largos e coriáceos.

Dwyer (1957) reduziu S. radlkoferi Rusby a variedade de $S$. guianense. Zarucchi \& Herendeen (1993) propuseram a nova combinação, T. guianensis, e realizaram a lectotipificação, designando o material de Rob. Schomburg 598 como lectótipo. Van der Werff (2008) considerou S. radlkoferi como sinônimo de T. guianensis. Tanto esse último autor, quanto Lima 

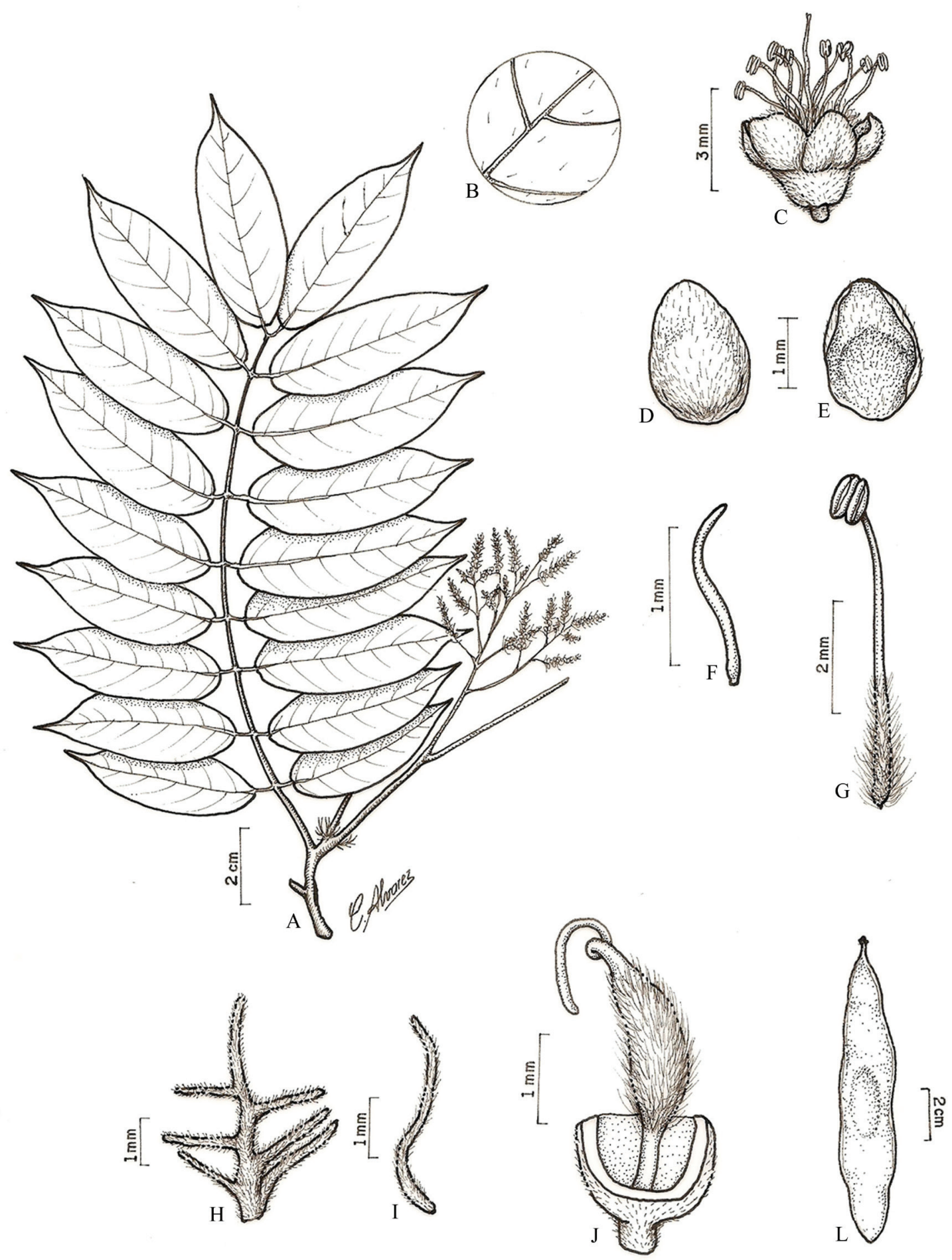

Figura 7. Tachigali guianensis (Benth.) Zarucchi \& Herend. A. Ramo florido. B. Detalhe da face abaxial do folíolo, evidenciando os tricomas. C. Flor. D. Sépala, face externa. E. Sépala, face interna. F. Pétala. G. Estame. H. Bráctea. I. Bractéola. J. Hipanto em secção longitudinal evidenciando a inserção do gineceu. L. Fruto. (A-B, H-I. G.C. Ferreira 120 (IAN); C-G e J. J. Lanjouw 1239 (IAN); L. N.A. Rosa 252 (IAN)).

Figure 7. Tachigali guianensis (Benth.) Zarucchi \& Herend.. A. Branch with inflorescence. B. Detail of the abaxial surface of leaves, showing the trichomes. C. Flower. D. Sepal, external surface. E. Sepals, inner surface. F. Petal. G. Stamen. H. Bract. I. Bracteole. J. Hypanthium in a longitudinal section showing the insertion of the gynoecium. L. Fruit. (A-B, H-I. G.C. Ferreira 120 (IAN); C-G e J. J. Lanjouw 1239 (IAN); L. N.A. Rosa 252 (IAN)). 
(2010c) consideraram T. guianensis como espécie e não como variedade, como havia sido proposto por Dwyer (1957). Ribeiro et al. (1999), na descrição de T. guianensis, indicaram a presença de domácias na raque principal, entretanto, no material examinado durante este trabalho, essas estruturas não foram observadas. Tachigali guianensis, na área de estudo, assemelha-se a $T$. vulgaris e $T$. paraensis, pelas pétalas lineares, mas distingue-se pelo pedicelo curto (ca. 0,5 mm compr.), e pelos frutos maiores (ca. $10 \mathrm{~cm}$ compr.), enquanto que T. paraensis apresenta pedicelo com ca. $1 \mathrm{~mm}$ diâm. e frutos com ca. $8,1 \mathrm{~mm}$ compr., e em T. vulgaris, o pedicelo mede ca. $2 \mathrm{~mm}$ compr. e o fruto ca. $8 \mathrm{~mm}$ compr.

7. Tachigali micropetala (Ducke) Zarucchi \& Pipoly, Sida 16(4): 787. 1995 ESclerolobium micropetalum Ducke, Bol. Técn. Inst. Agron. N. 2: 20. 1944. Tipo.

BRASIL. Amazonas: Manáos in silva primaria terris altis argillosis ultra locum Flores, 13-IV-1943, A. Ducke 1219 (síntipos IAN!, MG!, fotos dos isosíntipos $\mathrm{K}$ !, MO!, NY!, RB!).

Figura 8

Árvore 20-32 m alt., DAP ca. 35-38 cm. Folíolos 10-18; estípulas não vistas; pecíolo ca. $4 \mathrm{~cm}$ compr., cilíndrico, pubescente; raque ca. $23 \mathrm{~cm}$ compr., levemente canaliculada, pilosa. Folíolos 9-11 cm compr., 3,5-4 cm larg., elípticos, ápice acuminado; faces adaxial e abaxial glabrescentes; peciólulos ca. $2 \mathrm{~mm}$ compr., ca. $1 \mathrm{~mm}$ larg., semicilíndricos, pubescentes. Inflorescência com pedúnculo ca. $5 \mathrm{~cm}$ compr.; raque ca. 8,5 cm compr., levemente sulcada, pubescente; brácteas não vistas, bractéolas ca. $2 \mathrm{~mm}$ compr., subuladas, externa e internamente seríceas. Flores actinomorfas a ligeiramente zigomorfas; pedicelo ca. $2 \mathrm{~mm}$ compr.; hipanto ca. $1 \mathrm{~mm}$ compr., ca. 1,5 mm diâm.; sépalas, cimbiformes, externa e internamente glabrescentes, três maiores ca. $1,5 \mathrm{~mm}$ compr., ca. $1 \mathrm{~mm}$ larg., duas menores ca. $1 \mathrm{~mm}$ compr., ca. $0,8 \mathrm{~mm}$ larg.; pétalas ca. $1 \mathrm{~mm}$ compr., ca. $0,5 \mathrm{~mm}$ larg., obovadas, externamente glabras, internamente hirsutas no centro; anteras ca. 0,5 mm compr., ca. $0,3 \mathrm{~mm}$ larg.; filetes ca. $5 \mathrm{~mm}$ compr., densamente hirsutos da base até 1/2 do compr.; ovário 1,5-2 mm compr., ca. $1 \mathrm{~mm}$ larg., hirsuto; estípite ca. $1 \mathrm{~mm}$ compr., aderido à base ou à parede do hipanto; estilete 1,5-2 mm compr., glabro; óvulos 7. Fruto 10-20 cm compr., 1,5-2,5 cm larg., elíptico-oblongóide, liso, glabro; sementes não vistas.

Material examinado: BRASIL. PARÁ: Moju, Campo Experimental da Embrapa, 17-VIII-2010, M.S. Rodrigues 390 (IAN).
Rudas (1997) registrou a ocorrência de T. micropetala em bosque primário sobre solos arenosos do Peru. Segundo Lima (2010c), a espécie ocorre apenas em dois Estados da região Norte, ou seja, Pará e Amazonas, sendo uma espécie nativa, mas não endêmica do Brasil. Dwyer (1957), revisando o gênero Sclerolobium, comentou que Ducke (1944) enganou-se ao descrever as sépalas de S. micropetalum (T. micropetala) como sendo glabras. Enquanto algumas sépalas podem ser glabras, a maioria das flores dissecadas apresenta sépalas pubescentes. Da mesma forma, ao contrário da descrição de Ducke (1944), as pétalas são minuitamente pubescentes. Tachigali micropetala é facilmente reconhecida, principalmente devido às flores pequenas (Ducke 1949, Van der Werff 2008). Na obra princeps, Ducke (1944) informou que a espécie apresenta oito pares de folíolos e raramente se encontram sete ou nove pares. No material observado por Dwyer (1957) e Rudas (1997), as folhas apresentaram 7-8 pares de folíolos. No presente estudo, foram encontrados 5-9 pares de folíolos, porém no material adicional, depositado no herbário $\mathrm{MG}$, foram observados até 11 pares de folíolos.

Zarucchi \& Pipoly (1995) propuseram a nova combinação da espécie e classificaram como síntipos os tipos depositados nos herbários K, MO e NY; entretanto, Van der Werff (2008) comentou que o holótipo está depositado no IAN. No acervo do MG, também há uma duplicata desse material, que poderia ser o holótipo, visto que Ducke trabalhava nesse herbário. Como o autor não designou na obra princeps o holótipo optou-se, no presente trabalho, por considerar essas exsicatas como síntipos, concordando com Zarucchi \& Pipoly (1995).

Tachigali micropetala diferencia-se das outras espécies de Tachigali coletadas na área de estudo, por apresentar raque levemente canaliculada, pedúnculo ca. $5 \mathrm{~cm}$ compr., sépalas 1-1,5 mm compr., anteras ca. 0,5 mm compr., ca. 0,3 mm larg.. No entanto, as outras espécies do gênero apresentam raque canaliculada ou sem canalículo, pedúnculo 1,5-4,5 mm compr., sépalas $2-4 \mathrm{~mm}$ compr. e anteras 1-2 mm compr., 0,5-5 mm larg.

8. Tachigali paraensis (Huber) Barneby, Brittonia 48 (2): 182. 1996 ESclerolobium paraense Huber, Bol. Mus. Paraense Hist. Nat. 6: 79. 1910. Tipo: BRASIL. PARÁ: In silvis paraensibus ad vim ferream inter capitalemetBragança (EstaçãoExperimentalAugusto Montenegro), 8-IX-1908, Rodrigues s.n. (holótipo MG9642!, fotos dos isótipos K!, NY!, RB5620!). Figura 9 


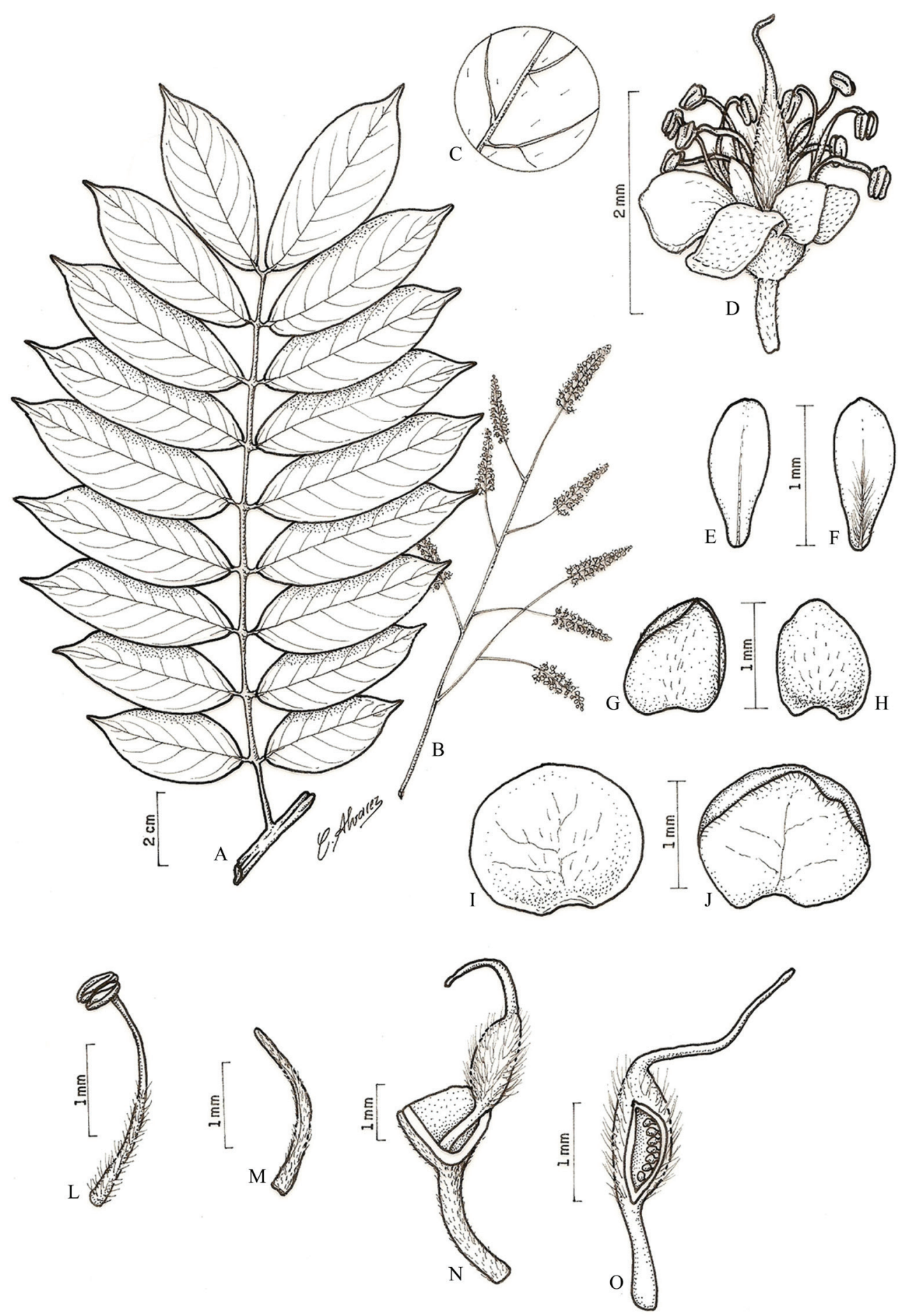

Figura 8. Tachigali micropetala (Ducke) Zarucchi \& Pipoly. A. Ramo. B. Inflorescência. C. Faces adaxial e abaxial do folíolo, evidenciando os tricomas. D. Flor. E. Pétala, face externa. F. Pétala, face interna. G. Sépala menor, face interna. H. Sépala menor, face externa. I. Sépala maior, face externa. J. Sépala maior, face interna. L. Estame. M. Bractéola. N. Hipanto em secção longitudinal evidenciando a inserção do gineceu. O. Ovário. (A e C. M.S. Rodrigues 390 (IAN); B, D-O. C.S. Rosário et al. 832 (IAN; MG)).

Figure 8. Tachigali micropetala (Ducke) Zarucchi \& Pipoly. A. Branch. B. Inflorescence. C. Detail of the adaxial and abaxial surface of leaflet, showing the trichomes. D. Flower. E. Petal, external surface. F. Petal, inner surface. G. Smaller sepal, inner surface. H. Smaller sepal, external surface. I. Larger sepal, external surface. J. Larger sepal, inner surface. L. Stamen. M. Bracteole. N. Hypanthium in a longitudinal section showing the insertion of the gynoecium. O. Ovary. (A and C. M.S. Rodrigues 390 (IAN); B, D-O. C.S. Rosário et al. 832 (IAN; MG)). 
Árvore 30-35 m alt., DAP ca. $46 \mathrm{~cm}$. Folíolos (5-)6(-7)-8; estípulas 2,5-3 cm compr., foliáceas, revolutas, glabras; pecíolo 4-4,7 cm compr.; raque 5,2-7 cm compr., ambos cílindricos, glabros ou glabrescentes. Folíolos 11-14 cm compr., 3,5-5 cm larg., opostos, elíptico-oblongos, ápice cuspidado, faces adaxial e abaxial glabras; peciólulos 5-6 mm compr., ca. 2 mm larg., rugosos, clilíndricos, pilosos a glabrescentes. Inflorescência com pedúnculo 1,5-3 cm compr.; raque 6,5-7 cm compr., levemente sulcada, serícea; brácteas 3 , uma na base, 5-7 mm compr., subulada, serícea, duas opostas, 2-2,8 cm compr., foliáceas, revolutas, glabras; bractéolas 2-4 mm compr., subuladas, externa e internamente seríceas. Flores actinomorfas a levemente zigomorfas; pedicelo ca. $1 \mathrm{~mm}$ compr.; hipanto 1-1,5 mm compr., ca. $2 \mathrm{~mm}$ diâm., seríceo; sépalas maiores 3 , ca. $3 \mathrm{~mm}$ compr., ca. $2 \mathrm{~mm}$ larg., cimbiformes, menores 2, ca. $2 \mathrm{~mm}$ compr., $1 \mathrm{~mm}$ larg., ambas externamente seríceas, internamente seríceas, hirsutas na base; pétalas 3,5-4 mm compr., lineares, densamente hirsutas; anteras ca. $1 \mathrm{~mm}$ compr., ca. 0,5 mm larg.; filetes ca. $5 \mathrm{~mm}$ compr., densamente hirsutos da base até $2 / 5$ do compr.; ovário ca. $2 \mathrm{~mm}$ compr., ca. $1 \mathrm{~mm}$ larg., hirsuto; estípite ca. $1,5 \mathrm{~mm}$ compr., aderido à base do hipanto; estilete ca. $3 \mathrm{~mm}$ compr., glabro; óvulos 5-7. Fruto ca. 8,1 cm compr., ca. 2,1 cm larg., obovóide, liso, glabro; semente 1, ca. 1,6 cm compr., ca. $1 \mathrm{~cm}$ larg., ovada, lisa, glabra.

Material examinado: BRASIL. PARÁ: Moju, Campo Experimental da Embrapa, 18-VI-2010, M.S. Rodrigues et al. 383 (IAN); idem, 16-VI-2010, M.S. Rodrigues et al. 381 (IAN); idem, 7-VII-2010, M.S. Rodrigues et al. 385 (IAN); idem, 7-VII-2010, M.S. Rodrigues et al. 384 (IAN); idem, 12-VI-2002, A.M. Ferreira 175 (IAN); idem, 9-V-2003, A.E. Silva-e-Silva et al. 4 (IAN).

Espécie com distribuição no Brasil, Suriname, Guiana Francesa, Venezuela, Equador e Peru (Van der Werff 2008, w3 Tropicos 2010). De acordo com Ducke (1949), Sclerolobium paraense (atualmente, Tachigali paraensis) ocorreria apenas no Pará, nas proximidades de Belém e estrada de ferro de Bragança (Peixe Boi), nas ilhas de Breves (Jaburuzinho), no Xingú (estradas ao oeste da volta), e no município de Óbidos. Entretanto, na lista das leguminosas da Amazônia (Silva et al. 1989) é indicada sua ocorrência, além do Pará, nos Estados do Amapá e Amazonas. Segundo Van der Werff (2008) e Lima (2010c), T. paraensis ocorre apenas em dois Estados brasileiros, ou seja, no Maranhão e no Pará.
Huber (1909), ao descrever S. paraense (atualmente, T. paraensis) considerou-a espécie afim de S. odoratissimum (atualmente, T. odoradissima), diferenciando-se pela base dos folíolos e pelo pedicelo curto. Ducke (1949) comentou que os espécimes de Manaus, outrora identificados como $S$. paraense (atualmente, $T$. paraensis), pertenciam, na verdade, a S. melanocarpus (atualmente, T. melanocarpa).

Devido ao ovário falcado, Dwyer (1957) considerou S. urbanianum (atualmente, T. urbaniana) como espécie afim de $S$. paraense (atualmente, $T$. paraensis), comentando que essa última pode ser prontamente reconhecida pelas estípulas muito grandes que, geralmente, são persistentes. O autor explicou que não viu o tipo de $S$. paraense (atualmente, T. paraensis), entretanto, no material que examinou, encontram-se os exemplares Rodrigues 9642 e Siqueira 5620, que na verdade correspodem a uma mesma coleta, ou seja são duplicatas e isótipos. Examinando essas amostras depositadas nos herbários MG e RB, foi possível observar que Rodrigues e Siqueira são duas partes do nome de uma mesma pessoa (Rodolfo Siqueira Rodrigues), e que os números 9642 e 5620 são os registros dos herbários MG e $\mathrm{RB}$, respectivamente, e não números de coleta. $\mathrm{O} M G$ doou a duplicata ao $\mathrm{RB}$, e na respectiva etiqueta há o nome do coletor e o registro no Herbário (MG9642); essa exsicata ao ser incorporada ao acervo do RB recebeu o número RB5620. Nos herbários K e NY, há duplicatas desse material com etiqueta do RB5620 e após o nome do coletor há a seguinte informação: "Herb. Amaz. Mus. Pará 9642".

Segundo Van der Werff (2008), a espécie é reconhecida também pelos folíolos cuneados ou assimétricos na base, pelas brácteas pequenas, persistentes e revolutas, e pelas pétalas lineares densamente hirsutas, esse autor considerou T. melanocarpa similar a T. paraensis. Foram observados, tanto no material provenintes do Campo Experimental quanto no material adicional, ramos contendo folhas pari e imparipinadas.

$\mathrm{Na}$ área de estudo, T. paraensis assemelha-se a T. vulgaris e T. guianensis com os quais compartilham as pétalas lineares, contudo, diferencia-se dessas pelo número de folíolos (5-)6(-7)-8 e pétalas densamente hirsutas.

9. Tachigali vulgaris L.G. Silva \& H.C. Lima, Rodriguésia 58(2): 397. $2007 \equiv$ Sclerolobium paniculatum Vogel, Linnaea 11: 397. 1837, non Tachigali vulgaris Aubl. (1775). Tipo: BRASIL. Mato Grosso: In regione Cujabá prov. Matto-Grosso in sylvis, 2-XI-1815, Silva Manso \& Lhotskys.n. (holótipo B, foto do isótipo MO2209334!). Figura 10 


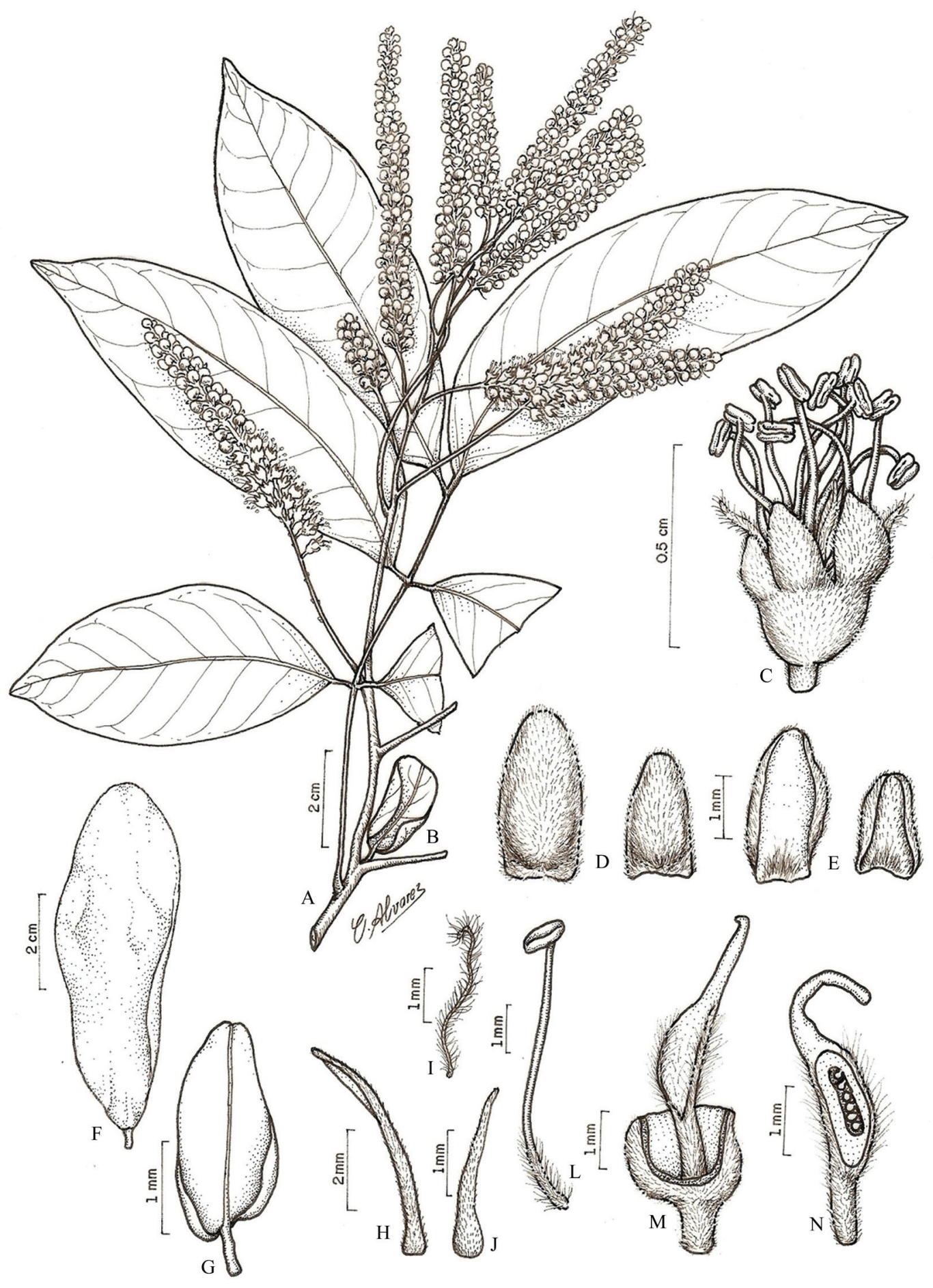

Figura 9. Tachigali paraensis (Huber) Barneby. A. Ramo florido. B. Estípula. C. Flor. D. Sépala maior e menor, face externa. E. Sépala maior e menor, face interna. F. Fruto. G. Bráctea foliácea. H. Bráctea subulata. I. Pétala. J. Bractéola. L. Estame. M. Hipanto em secção longitudinal evidenciando a inserção do gineceu. N. Ovário em secção longitudinal. (A-E, G-N. M.S. Rodrigues 384 (IAN); F. A.E. Silva-e-Silva 04 (IAN)).

Figure 9. Tachigali paraensis (Huber) Barneby. A. Branch with inflorescence. B. Stipule. C. Flower; D. Larger and smaller sepal, external surface. E. Larger and smaller sepal, inner surface. F. Fruit. G. Foliaceous Bracts. H. Subulate bract. I. Petal. J. Bracteole. L. Stamen. M. Hypanthium inn a longitudinal section showing the insertion of the gynoecium. N. Ovary in longitudinal section. (A-E, G-N. M.S. Rodrigues 384 (IAN); F. A.E. Silva \& Silva 04 (IAN)). 
Árvore ca. $8 \mathrm{~m}$ alt., DAP ca. $12 \mathrm{~cm}$. Folíolos 14, estípulas precocemente caducas; pecíolo ca. 9,3 cm compr.; raque ca. 25,5 cm compr., ambos semicílindricos, velutinos. Folíolos ca. $10 \mathrm{~cm}$ compr., ca. $5 \mathrm{~cm}$ larg., oblongo-ovados, ápice acuminado; face adaxial glabrescente, abaxial serícea; peciólulos ca. $7 \mathrm{~mm}$ compr., ca. $2 \mathrm{~mm}$ larg., levemente rugosos, semicilíndricos, seríceos. Inflorescência com pedúnculo ca. $3,5 \mathrm{~cm}$ compr.; raque ca. $16 \mathrm{~cm}$ compr., lisa, velutina; brácteas não vistas; bractéolas ca. $4 \mathrm{~mm}$ compr., subuladas, externa e internamente seríceas. Flores actinomorfas; pedicelo ca. $2 \mathrm{~mm}$ compr.; hipanto ca. $1 \mathrm{~mm}$ compr., ca. 1,5 mm diâm., seríceo; sépalas ca. 2,5 mm compr., ca. $1 \mathrm{~mm}$ larg., cimbiformes, externamente seríceas, internamente hirsutas basalmente; pétalas ca. $2 \mathrm{~mm}$ compr., lineares, glabras; anteras ca. $1 \mathrm{~mm}$ compr., ca. 0,5 mm larg.; filetes ca. $4 \mathrm{~mm}$ compr., densamente hirsutos da base até $1 / 2$ do compr.; ovário ca. $3 \mathrm{~mm}$ compr., ca. $1 \mathrm{~mm}$ larg., hirsuto; estípite ca. $1 \mathrm{~mm}$ compr., aderido à base do hipanto; estilete ca. $3 \mathrm{~mm}$ compr., glabro; óvulos 6 . Fruto ca. $6 \mathrm{~cm}$ compr., ca. 1,5 cm larg., oblongóide a obovóide, liso, glabro; semente 1, ca. $8 \mathrm{~mm}$ compr., ca. $5 \mathrm{~mm}$ larg., oblonga, lisa, glabra.

Material examinado: BRASIL. PARÁ: Moju, Campo Experimental da Embrapa, 24-X-1995, B.G.S. Ribeiro 1887 (IAN).

Tachigali vulgaris é uma espécie endêmica do Brasil, onde é registrada para as regiões Nordeste (Maranhão, Piauí, Ceará e Bahia), Centro Oeste (Mato Grosso, Goiás, Distrito Federal e Mato Grosso do Sul) e Norte (Pará, Amazonas e Tocantins), ocorrendo nos domínios fitogeográficos da Caatinga, Cerrado e Amazônia (Lima 2010c).

Bentham (1870) considerou três variedades para Sclerolobium paniculatum: S. paniculatum var. paniculatum, S. paniculatum var. subvelutinum Benth. e S. paniculatum var. rubiginosum (Mart. ex Tul.) Benth. Dwyer (1957) propôs S. paniculatum var. peruvianum Dwyer, de ocorrência apenas no Peru. Segundo Van der Werff (2008), S. paniculatum var. subvelutinum e $S$. paniculatum var. rubiginosum não ocorrem na floresta amazônica.

Oliveira Filho (2006) transferiu S. paniculatum var. subvelutinum e $S$. paniculatum var. rubiginosum para o gênero Tachigali, considerando-as como espécies. Silva \& Lima (2007) propuseram o nome T. vulgaris para substituir $S$. paniculatum, devido à existência de T. paniculata Aubl.
Segundo Van der Werff (2008), T. vulgaris é espécie comum e facilmente reconhecida pelos foliolos com base oblíqua e face abaxial serícea, estípulas caducas, domácias, pétalas lineares e glabras e pela base dos folíolos assimétrica. O mesmo autor comenta que T. tinctoria é muito similar e difere por apresentar flores sésseis.

Tachigali vulgaris, na área de estudo, mostra semelhança morfológica com $T$. guianensis e T. paraensis, devido à presença de pétalas lineares, porém se diferencia pelo tipo de indumento na face abaxial dos folíolos (seríceo), e comprimentos do pecíolo $(9,3 \mathrm{~cm})$, da raque da folha $(25,5 \mathrm{~cm})$, do pedicelo $(2 \mathrm{~mm})$ e dos frutos $(6 \mathrm{~cm})$.

10. Vouacapoua americana Aubl., Hist. Pl. Guiane: pl. 373. 1775. Tipo: GUIANA. s.d., Aublet s.n. (foto do tipo BM00063704!).

Figura 11

Árvore $15-33 \mathrm{~m}$ alt., DAP $24-78 \mathrm{~cm}$. Folhas pinadas; folíolos 7-11; estípulas não vistas; pecíolo 5,2-11,5 cm compr., cilíndrico ou semicilíndrico, pubescente nas folhas jovens e glabro nas folhas adultas; raque 5,5-18 cm compr., cilíndrica, pilosa nas folhas jovens e glabra nas folhas adultas, glândulas interfoliolares presentes. Folíolos 9,4-18 cm compr., 2,8-5,3 cm larg., opostos, ovado-elípticos, ápice acuminado, base arredondada; faces adaxial e abaxial glabras; peciólulos 5-8 mm compr., 1,3-2 mm larg., rugosos, canaliculados, glabros. Inflorescência em panícula terminal; pedúnculo $1-4 \mathrm{~cm}$ compr; raque 5-16,2 cm compr., sulcada ou levemente sulcada, velutina; brácteas ca. $3 \mathrm{~mm}$ compr., 1-1,8 mm larg., externa e internamente velutinas; bractéolas deltóides, externa e internamente velutinas, de tamanhos diferentes, uma maior, 2-2,5 mm compr., 1-2 mm larg., duas menores, 1,5-1,8 mm compr., 0,5-0,9 mm larg. Flores actinomorfas; pedicelo ca. $2 \mathrm{~mm}$ compr.; hipanto ca. 1,5 mm compr., ca. 2 mm diâm., velutino; cálice ca. $1 \mathrm{~mm}$ compr., gamossépalo, lacínias 5, ca. 2,5 mm compr., ca. $2 \mathrm{~mm}$ larg., oblongas, ápice arredondado ou cuneado, externa e internamente velutinas; corola dialipétala, pétalas ca. $4 \mathrm{~mm}$ compr., ca. 1,8 mm larg., obovadas, glabras; estames 10; anteras ca. 1,5 mm compr., 0,5-1 mm larg., glabras; filetes ca. $3 \mathrm{~mm}$ compr., dilatados na base, glabros; ovário ca. $2 \mathrm{~mm}$ compr., ca. $1 \mathrm{~mm}$ larg., densamente hirsuto; estípite ca. $0,5 \mathrm{~mm}$ compr., aderido à base do hipanto; estilete ca. $0,7 \mathrm{~mm}$ compr., glabro; estigma ciliado; óvulo 1. Fruto legume, 6,5-8 cm compr., 


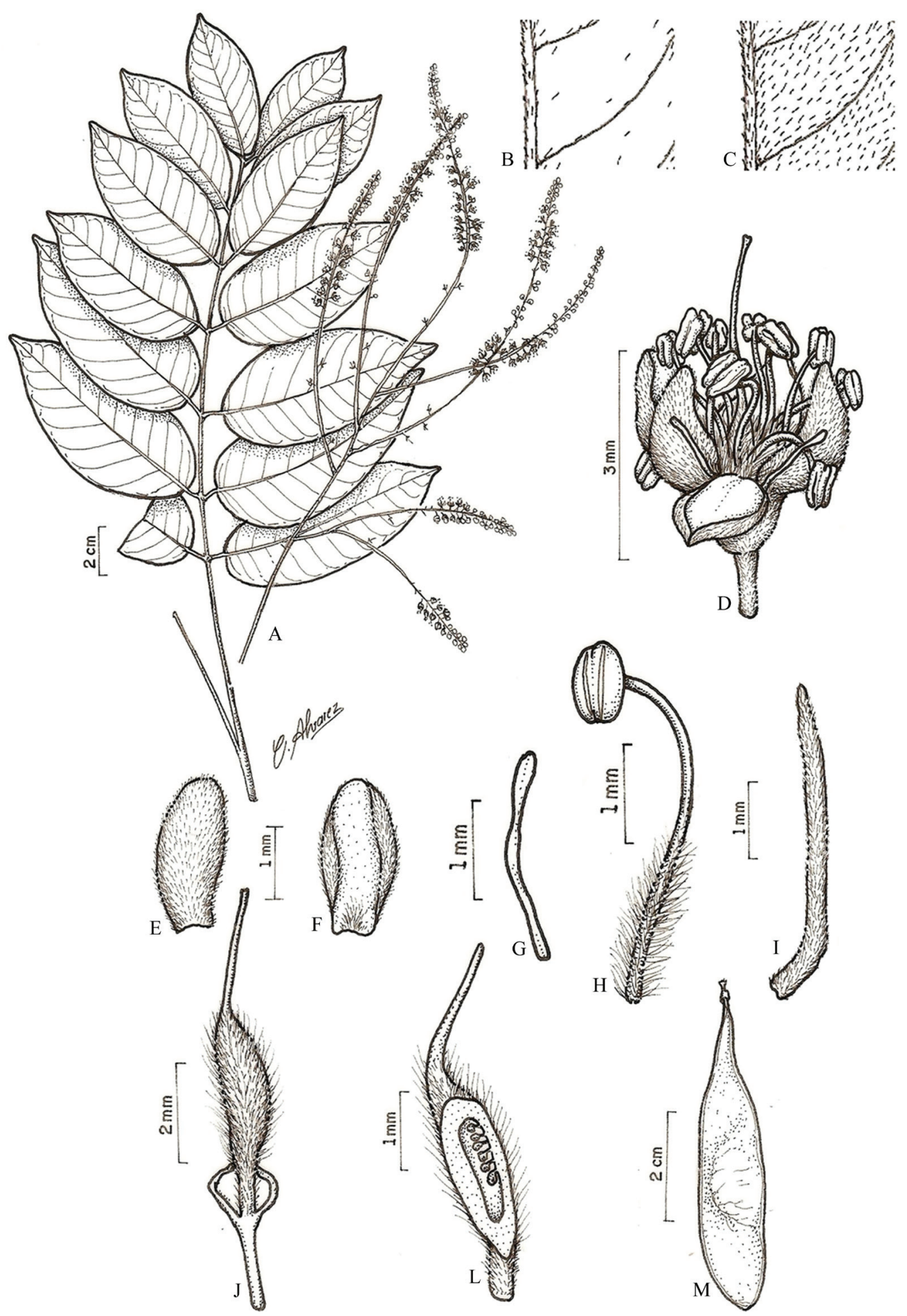

Figura 10. Tachigali vulgaris L.G. Silva \& H.C. Lima. A. Ramo florido. B. Detalhe da face adaxial do folíolo, evidenciando os tricomas. C. Detalhe da face abaxial do folíolo, evidenciando os tricomas. D. Flor. E. Sépala face externa. F. Sépala face interna. G. Pétala. H. Estame. I. Bractéola. J. Hipanto em secção longitudinal evidenciando a inserção do gineceu. L. Ovário em secção longitudinal. M. Fruto. (A- H, J-L. B.G.S. Ribeiro 1887 (IAN); I e M. M.S. Rodrigues 371 (IAN)).

Figure 10. Tachigali vulgaris L.G. Silva \& H.C. Lima. A. Branch and inflorescence. B. Detail adaxial surface of leaves, showing the trichomes. C. Detail of the abaxial surface of leaves, showing the trichomes. D. Flower. E. Sepal external surface. F. Sepal inner surface. G. Petal. H. Stamen. I. Bracteole. J. Hypanthium in a longitudinal section showing the insertion of the gynoecium. L. Ovary in longitudinal section. M. fruit. (A- H, J-L. B.G.S. Ribeiro 1887 (IAN); I and M. M.S. Rodrigues 371 (IAN)). 

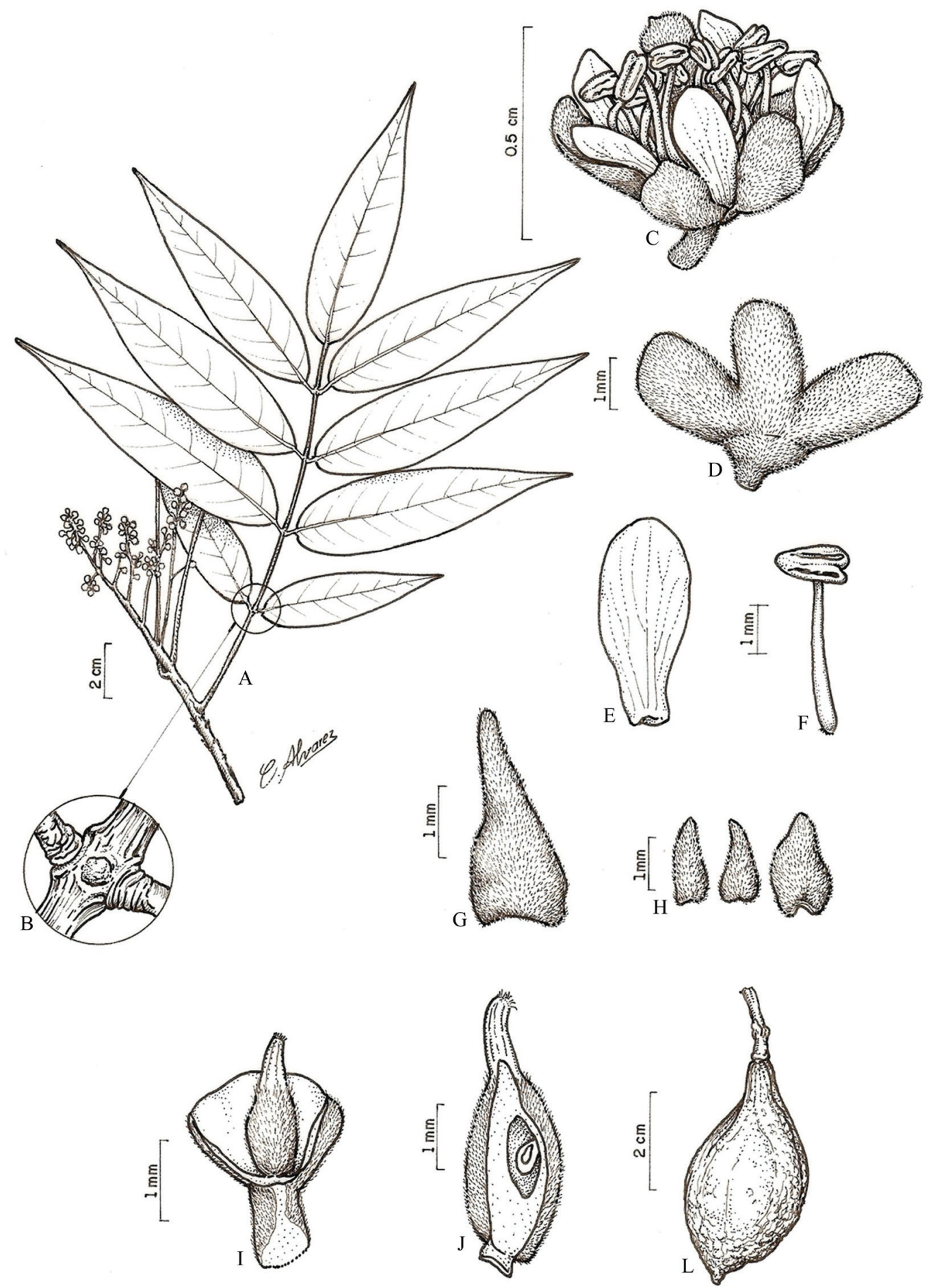

Figura 11. Vouacapoua americana Aubl. A. Ramo florido. B. Glândula interfoliolar. C. Flor. D. Cálice. E. Pétala. F. Estame. G. Bráctea. H. Bractéolas. I. Hipanto em secçõ longitudinal evidenciando a inserção do gineceu. J. Ovário em secção longitudinal. L. Fruto. (A e B. M.P. Nascimento 245 (IAN); C-F, I-L. G.C. Ferreira 648 (IAN); G e H. A.M. Ferreira 146 (IAN)).

Figure 11. Vouacapoua americana Aubl. A. Branch with inflorescence. B. Interfoliolar gland. C. Flower. D. Calyx. E. Petal. F. Stamen. G. Bract. H. Bracteoles. I. Hypanthium in a longitudinal section showing the insertion of the gynoecium. J. Ovary in longitudinal section. L. Fruit (A and B. M.P. Nascimento 245 (IAN); C-F, I-L. G.C. Ferreira 648 (IAN); G and H. A.M. Ferreira 146 (IAN)). 
2-4 cm larg., elipsóide a obovóide, rugoso, velutino; semente 1, ca. 2,3 cm compr., ca. 1,2 cm larg., esférica, lisa, glabra.

Material examinado: BRASIL. ParÁ: Moju, Campo Experimental da Embrapa, 26-II-2003, M.P. Nascimento 245 (IAN); idem, 30-I-2001, G.C. Ferreira 648 (IAN); idem, 22-II-2002, A.M. Ferreira 146 (IAN); idem, 25-III-1996, B.G.S. Ribeiro 2119 (IAN); idem, 11-III-1996, B.G.S. Ribeiro 2123 (IAN); idem, 28-III-1996, B.G.S. Ribeiro 2158 (IAN); idem, 29-III-1996, B.G.S. Ribeiro 2188 (IAN); idem, 9-III-1997, R.C.V. Martins-da-Silva 34 (IAN); idem, 30-I-2002, L.C. Procópio 459 (IAN).

Ocorre na Guiana Francesa e no Brasil (Ducke 1949, Ulibarri 2008). De acordo com Silva et al. (1989) e Lima (2010d), ocorre no norte do Brasil, nos Estados do Pará, Amapá e Amazonas. Já segundo Rizzini (1990), Rizzini \& Mors (1995) e Lima (2010d), no Nordeste ocorre apenas no Maranhão. Lorenzi (2002) afirmou que essa espécie é característica e exclusiva da mata pluvial Amazônica de terra firme, onde é medianamente frequente, porém de dispersão irregular e descontínua; ocorre, preferencialmente, no interior da mata primária, em terrenos planos com solos argilosos bem supridos de umidade.

$\mathrm{Na}$ obra princeps de $V$. americana, não há informação sobre o tipo, nem onde está depositado. Segundo Ulibarri (2008), o holótipo encontra-se no Herbário P e um isótipo no Herbário BM, mas o mesmo não examinou esse material.

Vouacapoua americana foi descrita por Aublet no apêndice da sua obra p. 9-11 e ilustrada pela estampa 373. Foi transferida por Bentham (Bentham 1938 citado por Huber 1906) para o gênero Andira. Huber (1906) informou que, como não pode consultar o trabalho de Bentham, publicado nos "Annalen des Wiener Hofmuseums" (1838 vol. II p. 108), não sabia quais as razões que levaram aquele autor a reunir os gêneros Vouacapoua e Andira. Huber (1906) comentou que, enquanto Bentham chamava o acapu de Andira aubletii, Otto Kuntze, querendo reivindicar a Aublet a prioridade do gênero Vouacapoua, caiu no outro extremo, subordinando todas as espécies de Andira, conhecidas à época, com o integrante de Vouacapoua; essa posição foi seguida por Taubert (1981).

Segundo Huber (1906), o gênero Vouacapoua distingue-se de Andira por apresentar os frutos deiscentes, enquanto em Andira os mesmos são indeiscentes, caráter que, segundo o autor não permitiria reuní-los. Mesmo no caso de não existirem outras diferenças e não sendo possível olhar as flores, seria necessário separar os gêneros Vouacapoua e Andira; conservando $V$. americana e reunindo, no gênero Andira, todas as outras espécies de fruto drupáceo e indeiscente.

Vouacapoua americana é semelhante morfologicamente a $V$. pallidior, mas se separam, segundo Rizzini (1990), pelo fato de $V$. americana apresentar flores menores, madeira escura e brácteas e bractéolas superando em tamanho o pedicelo.

Sousa \& Lorenzi (2005), baseando-se em dados moleculares (APG II 2003), consideraram o gênero Vouacapoua em Papilionoideae, entretanto, Lewis et al. (2005), também baseados em dados moleculares, classificam-no em Caesalpinioideae.

A espécie é facilmente reconhecida, no campo, por apresentar depressões profundas distribuídas ao longo do tronco. Assemelha-se a Batesia floribunda, por apresentar três bractéolas, glândulas interfoliolares, cálice gamossépalo, corola dialipétala e estigma com tricomas, porém $V$. americana diferencia-se pelos folíolos de 7-11, lanceolados ou ovalados, pecíolo plano e fruto do tipo legume.

\section{Lista de exsicatas}

I.V. Amaral et al. 853 (MG) (9); W.R. Anderson 10853 (IAN) (2), $10858 B$ (IAN) (2), 10894 (IAN) (2), 11043 (IAN) (2); A.C. Andrade 27 (IAN) (4); S. Almeida et al. 00383 (MG) (10); S.S. Almeida 60 (MG) (2), 253 (MG) (2); Altson 348 (K, RB) (3); J. Aluizio 246 (INPA) (1); W.A. Archer 8043 (IAN) (4); P.A.C.L. Assunção 734 (INPA) (1), 853 (MG) (9); P.A.C.L. Assunção \& C.F. Silva 643 (INPA) (6); T.R. Bahia 143 (MG) (2); 203 (MG) (2); J.T. Baldwin 3271 (IAN) (2), 3439 (IAN) (2), 4015 (IAN) (4), $4017 a$ (IAN) (2); M.N.C. Bastos et al. 2293 (MG) (1); H.T. Beck 365 (INPA) (1); C.C. Berg \& A. Henderson 492 (MG) (9); G.A. Black 834 (IAN) (10), 47-1164 A (IAN) (2), 47-1267 (IAN) (2), 47-1768 (IAN) (2), 47-1813 (IAN) (9), 52-15509 (IAN) (9); 54-16305 (IAN) (2), 54-16574 (INPA) (4), 55-18617 (IAN) (9); G.A. Black \& P. Ledoux 50-10748 (IAN) (2), 50-10491 (IAN) (9); G.A. Black et al. 50-9850 (IAN), (2), 51-13392 (IAN) (6); L.C. Blanch 77-A (INPA) (4); W. Bockermann 264 (IAN) (9); R. Boyan 286 (INPA) (1); M.T. Campos 32 (INPA) (1); Capucho 351 (IAN) (2); N.A.S Carmo 09 (IAN) (3); L.S. Carneiro 29 (IAN) (4); A.A. Carpanezzi 04 (IAN) (9); L. Carreira et al. 557 (IAN, 
MG) (9); P. Cavalcante 240 (MG) (4), 1385 (MG) (10), 2962 (MG) (2); P. Cavalcante \& M. Silva 1671 (IAN) (2), 1703 (MG; IAN) (9); 2874 (MG) (2); C.A. Cid et al. 919 (MG) (5); D. Coêlho s.n. (INPA3400) (1), 3987 (MG) (5); D. Coêlho \& F Mello s.n. (INPA3160) (1); D. Coêlho \& W. Rodrigues 7533 (INPA) (1); L.S. Coêlho et al. 147 (INPA) (2); L. Coradin \& M.R. Cordeiro 734 (INPA, IAN) (4); M.R. Cordeiro 787 (IAN) (4), 1025 (1), 1120 (MG) (9), 4730 (IAN) (6), 4833 (IAN) (1), MC-01-07 (100.222) (IAN) (2), MC-07-19 (100.329) (IAN) (6), MC-12-17 (100.398) (IAN) (1); J. Cruz et al. 70 (INPA) (2); R.S. Cowan 38354 (IAN) (10); C.N. Cunha et al. 762 (MG) (9); D.C. Daly 6945 (INPA) (4); D.C. Daly et al. D721 (MG, IAN) (9), 1182 (INPA, IAN, MG) (10); M. Dantas \& M.R. Cordeiro 1426 (IAN) (2); A.T.G. Dias 20 (MG) (2), 475 (MG) (2), 774 (MG) (2), 486 (MG) (2); C. Dick \& E. Palheta 978 (INPA) (1); Dionisio 3456 (MG) (2); A. Ducke s.n. (MG 759) (9), (MG15526) (1), s.n. (MG16580) (8), s.n. (MG 17227) (5), s.n. (US1442409; MG 17075) (5), s.n. (MG 17110) (5), 655 (IAN; MG) (9), 884 (MG) (4), 932 (MG; IAN) (5), 1146 (IAN, MG) (1), 1219 (IAN, K, MG, MO, NY) (7), 1561 (MG) (9), 1712 (MG, IAN) (8), 2925 (MG) (2), 8063 (MG) (9), 9895 (MG) (9), 10311 (MG) (9), 11212 (IAN) (9), 12111 (MG) (8), 15447 (MG) (2), 16324 (MG) (8), 16601 (MG) (10); 16699 (MG) (1), W.A. Engler 356 (MG) (9), 409 (MG) (9), 662 (MG) (2); W.A. Engler \& H.S. Irwin 46071 (IAN) (2); $F \&$ L 3256 (IAN) (2); J. Elias 275 (MG) (8), 284 (MG) (8); C. Farias s.n (INPA) (4); L.P. Félix \& M.F.O. Pires 7787 (INPA) (4); C. Fernades-Bulhão 046 (INPA) (9); Fernando \& Black 48-3116 (IAN) (2); A.M. Ferreira 146 (IAN) (10), 168 (1), 175 (IAN) (8); C. Ferreira 9732 (INPA) (1); C.A. Ferreira et al. 6471 (MG) (9); C.A.C. Ferreira 9796 (MG) (9), 11190 (INPA) (9), 12406 (IAN) (9); C.A.C. Ferreira et al. 6407 (MG) (9), 7977 (INPA) (2); G.C. Ferreira 120 (IAN) (6), 400 (IAN) (3), 463 (IAN) (3), 648 (IAN) (10), 901 (MG, INPA) (9); G.C. Ferreira \& J.C. Freitas 588 (IAN) (2); J. França 450 (INPA) (4); J.C. Freitas 01 (IAN) (9), 02 (IAN) (9), 03 (IAN) (9), 06 (IAN) (9), 07 (IAN) (9); M.A. Freitas et al. 978 (INPA, MG) (1); R.L. Fróes 19897 (IAN) (6), 20452 (IAN) (9), 22713 (IAN) (2), 21115 (IAN) (2), 25449 (IAN) (2), 25907 (IAN) (10), 26250 (1), 26333 (IAN) (2), 26352 (IAN) (2), 26502 (IAN) (2), 29920 (IAN) (9), 30576 (IAN) (9), 30938 (IAN) (8), 31244 (IAN) (2), 31340 (IAN) (2), 31462 (IAN) (9), 31520 (IAN) (10), 31547 (IAN) (10), 32856 (IAN) (5), 33162 (IAN) (2), 33203 (IAN) (2), 33595
(IAN) (2), 34695 (IAN) (8); R.L. Fróes \& G. Addison 29027 (IAN) (2); R.L. Fróes \& G.A. Black 24375 (IAN) (4), 24776 (IAN) (2), 27614 (IAN) (2); R.L. Fróes et al. 29080 (IAN) (2); G. Gardner 1277 (K) (4); T.B. Garcia \& J.S. Souza 01 (MG) (4); A. Goeldi 10780 (MG) (10); T. Guedes 84 (IAN) (1), 124 (IAN) (4), 669 (IAN, MG) (1); J. Grogan 198 (IAN; INPA) (9); A. Henderson et al. 463 (INPA) (4); M. Henrique s.n (MG165384) (9); I. Huber 810 (MG) (2), 973 (MG) (2); H.S. Irwin \& T.R. Soderstrom 6583 (IAN) (9); H.S. Irwin et al. 261469 (MG) (6); J. Jangoux \& R.P. Bahia 1102 (INPA, MG) (4); S. Kell \& J. Guedes 262 (MG) (2); O.H. Knowles avulso12 (MG) (9); K. Kubitzki 79-71 (MG) (2), 84-316 (MG) (4), 84-392 (MG) (2); M. Kuhlmann \& S. Jimbo 42 (MG, IAN) (8), 291 (MG) (1); J. Lanjouw 1239 (IAN) (6); D.A. Lima 53-1354 (IAN) (9); F. Lima 10781 (MG) (10); (10); H.C. Lima et al. 6781 (MG) (9); J.M.S. Lima s.n. (INPA215009) (4), s.n. (INPA215041) (4); J.C.A. Lima \& M.M. Santos 158 (INPA) (4); P. Lisboa 1442 (MG) (2); R. Lisboa et al. 6828 (MG) (2); L.C.B. Lobato 2886 (MG) (9); M.G.A. Lobo et al. 94 (MG) (9); M. Macedo et al. 3893 (MG) (9); U.N. Maciel \& M.R. Cordeiro 77 (MG) (2), 197 (INPA, IAN, MG) (4), 250 (IAN; MG) (9); U.N. Maciel et al. 806 (INPA) (2); F. Magalhães 13 (INPA) (4); F.M.M. Magalhães F531 (INPA) (4); Manso \& Lhotsky s.n. (MO2209334) (9); L.R. Marinho 454 (IAN) (2); R.C.V. Martins-da-Silva 34 (IAN) (10); J.M.S. Miralha et al. 190 (INPA) (1); O.P. Monteiro 57 (INPA) (10); J.C. Moraes 1017 (IAN) (4); S. Mori et al. 16545 (MG) (6); C.D Mota \& L. Coêlho 166 (INPA) (4); J.R. Nascimento \& C.F. Silva 609 (INPA) (1); M.P. Nascimento s.n. (IAN) (4), 226 (IAN) (3), 245 (IAN) (10); O.C. Nascimento 518 (MG) (9); M.A. Neves 04 (INPA) (4); A. Nitta 17396 (IAN; MG) (4), 17423 (IAN; MG) (4), 17869 (MG) (4); F. Norberto \& N.A. Rosa 175 (MG) (9); E. Oliveira 41 (IAN) (2), 197 (IAN) (8), 250 (IAN) (1), 1260 (IAN) (2), 1893 (IAN) (10), 2497 (IAN) (10), 4316 (IAN) (2), 4857 (IAN) (2), 4867 (IAN) (10), 5752 (IAN) (2); D.R. Oliveira 146 (INPA) (4); J. Oliveira \& A.C.A. Cortez s.n. (INPA216257) (4); J.C.L. Oliveira 428 (IAN) (5); A.A. Oliveira et al. 319 (INPA) (1); R.P. Orlandi 874 (MG) (9); M. Pacheco et al. 117; B.S. Pena 98 (IAN) (2), 280 (IAN) (2), 574 (IAN) (2); D. Philcox et al. 3125 (IAN) (9), 3237 (IAN) (9), 3528 (IAN) (9), 3701 (IAN) (9); G.C. Perreira Pinto 26358 (MG) (2); Pessoal do horto florestal RB 887 (IAN) (4); Pessoal do L.P.F./Brasília 0966 (INPA) (8); A.S. Pinkus 07 (IAN) (3); J.M. Pires 85 (IAN) (2), 2660 (IAN, INPA) 
(1), 3104 (INPA, IAN) (10), 6299 (IAN) (9), 13092 (IAN) (9), 11928 (IAN, MG) (8), 11930 (IAN) (8); J.M. Pires \& G.A. Black 578 (IAN) (4), 1135 (IAN) (9), 1233 (IAN) (10), 2224 (IAN) (9); J.M. Pires \& P.P. Furtado 17107 (MG) (9); J.M. Pires \& M.R. Santos 16551 (MG) (9); J.M. Pires \& N.T. Silva 2030 (MG) (10), 4510 (IAN, INPA) (1), 11291 (IAN) (2); J.M. Pires \& N.A. Rosa 13656 (IAN) (1); J.M. Pires \& N.T. Silva 10607 (IAN) (2), 11119 (IAN) (10), 11120 (IAN) (10), 11222 (IAN) (10), 11344 (IAN) (10), 11432 (IAN) (10), 11453 (IAN) (10), 11465 (IAN) (10), 11509 (IAN) (10), 11702 (IAN) (10), 11801 (IAN) (8); J.M. Pires et al. 4864 (IAN) (5), 50943 (MG, IAN) (6), 5111 (IAN) (1), 51242 (MG, IAN) (5), 14.112 (MG) (2), 14.118 (MG, IAN) (2); T. Plowman et al. 8802 (IAN) (9); G.T. Prance 25011 (MG) (9); G.T. Prance \& T.D. Pennington 2009 (IAN) (1); G.T. Prance \& W.C. Steward 20146 (INPA) (4); G.T. Prance et al. 2640 (MG) (2), 3471 (INPA) (1), 3930 (INPA, MG), 5287 (MG) (2), 9087 (MG) (2), 11483 (MG) (9), 13743 (MG) (2), 15102 (MG) (2); 15126 (MG) (2), 24330 (INPA) (1); A.M. Procópio 384 (IAN) (1); L.C. Procópio 415 (IAN) (3), 443 (IAN) (3), 448 (IAN) (3), 459 (IAN) (10). J.B. Rabelo 879 (MG) (2), 879 (MG) (2); B. Rabelo \& R. Non 778 (MG) (6); B. Rabelo \& C. Pen 988 (MG) (4); B.V. Rabelo et al. 3601 (INPA) (1); J.F. Ramos 2929 (INPA) (9); J.A. Ratter et al. 1847 (IAN) (9); B.G.S. Ribeiro 263 (IAN) (2), 1887 (IAN) (9), 2022 (IAN) (6), 2119 (IAN) (10), 2123 (IAN) (10), B.G.S. Ribeiro 2158 (IAN) (10), 2188 (IAN) (10), 2362 (IAN) (4); M.N.S. Ribeiro s.n. (INPA187507) (4); R.D. Ribeiro et al. 1136 (MG) (9), 1176 (MG) (9); J. Revilla et al. 4491 (INPA) (2); L. Riedel 83 (K) (2); A.E.S. Rocha (MG) (9); W. Rodrigues \& D. Coêlho 5618 (INPA) (1); E. Rodrigues 031 (INPA) (4); I.A.C. Rodrigues 432 \& M. Dantas 211 (IAN) (9); I.A. Rodrigues 1452 (IAN) (10); I.A. Rodrigues et al. 1131 (IAN) (2), 1057 (IAN) (2), 1085 (IAN) (4); M.S. Rodrigues 371 (IAN) (9), 381 (IAN) (8), 382 (IAN) (3), 383 (IAN) (8), 385 (IAN) (8), 384 (IAN) (8), 390 (IAN) (7), 393 (IAN) (3), 394 (IAN) (3); M.S. Rodrigues \& M.P. Nascimento 372 (IAN) (4); M.S. Rodrigues \& J.C.L. Oliveira 379 (IAN) (4); M.S. Rodrigues et al. 395 (IAN) (2); R.S. Rodrigues s.n (K000264440, MG9642, NY00007344, RB5620) (8); W. Rodrigues 8395 (INPA) (4); N.A. Rosa 252 (IAN) (6), 514 (IAN) (2), 530 (IAN) (2), 771 (IAN) (9), 3647 (MG) (2), 4350 (MG) (6); N.A. Rosa \& Alfeu 4399 (MG) (2); N.A. Rosa \& M.R. Santos 1917 (INPA) (2); C.S. Rosário 977 (MG) (8); C.S.
Rosário et al. 832 (IAN, MG) (7), 977 (IAN) (8); Rozemiro 32 (MG) (8); J. Sales \& C. Rosário 50 (MG) (9); R.P. Salomão 1017 (MG) (2), 1018 (MG) (2); M.R. Santos 66 (1); J.U. Santos et al. 658 (MG) (9); W.S.S. Santos et al. 10 (MG) (2); A.C. Sarmento 638 (MG) (9); R.E. Schultes \& F. López 954 (IAN) (2), 9676 (IAN) (1); Scluele 9082 (MG) (2); R. Secco \& Cardoso 0666 (MG) (9); A.E. Silva-e-Silva et al. 04 (IAN) (8); A.S.L. Silva 344 (MG) (9), 1456 (INPA) (10), 4303 (MG) (2); A.S.L. Silva et al. 557 (IAN, INPA, MG) (1), 1397 (MG, IAN) (9), 1965 (MG) (9), 3600 (MG) (1), 3601 (MG) (10), 3826 (MG) (1), 4044 (MG) (9); J.B.F. Silva et al. 873 (MG) (9); J.F. Silva 51 (IAN) (4); M. Silva 550 (MG) (2), 574 (MG) (2), 684 (MG) (8), 1138 (MG) (2), 1661 (MG) (2), 1675 (MG) (2); M. Silva \& R. Souza 2-257 (MG) (5), 2332 (MG) (5); M.B. Silva 13 (IAN) (4); M.F. Silva et al. 2432 (MG) (9); M.G. Silva \& C. Rosário 3625 (MG) (2), 5341 (INPA) (2); M.G. Silva \& R. Bahia 3102 (MG, IAN) (2); M.G. Silva et al. 2733 (MG) (2); N.T. Silva 53 (IAN) (8), 343 (IAN) (1), 833 (IAN) (1), 898 (IAN) (5), 955 (IAN) (5), 1015 (IAN) (5), 1191 (IAN) (5), 2566 (IAN) (5), 2580 (IAN) (5), 2738 (IAN) (5), 2760 (IAN) (5), 2814 (IAN) (5), 2996 (IAN) (10), 3055 (IAN) (2), 3086 (IAN) (10), 3130 (IAN) (8), 3243 (IAN) (8), 3322 (IAN) (7), 3427 (IAN) (8), 4288 (IAN) (2), 5144 (MG) (8), 5194 (MG) (5), 5217 (INPA, MG) (1), 5220 (INPA, MG) (10), 5451 (MG) (8), 59731 (IAN) (4); N.T. Silva \& B.S. Ribeiro s.n. (IAN) (9); S.F. Silva $215 A$ (INPA) (4); V. Sobrinho 271 (IAN) (4); R. Schomburg 598 (NY; K) (6); L.L. Sousa \& J.C. Reis 0106 (MG) (2), 0107 (MG) (2); L.A.G. Souza 505 (INPA) (4); L.A.G. Souza \& A. Cortez 0309 (INPA) (4); M.A.D. Souza 1568 (IAN) (2); S.A.M. Souza et al. 708 (IAN) (10); C.R. Sperling et al. 6108 (MG) (2); R. Spruce 2780 (K, RB) (1); G.L. Sobel et al. 4555 (MG) (1), 4741 (MG) (2); A. Tavarez et al. 307 (INPA) (1); E.L. Taylor et al. 1274 (MG) (9); W. Thomas et al. 4006 (MG) (9); R. Vilhena et al. 131 (MG) (2); C.E. Zartman 5796 (INPA) (9).

\section{Agradecimentos}

Ao $\mathrm{CNPq}$, pela bolsa concedida à primeira autora (Processo $\left.n^{\circ} 132808 / 2009-9\right)$, ao Dr. Ricardo Secco (Processo $n^{\circ} 303424 / 2010-9$ ); ao pesquisador do Museu Goeldi, Antônio Sérgio Lima da Silva, pela confirmação das identificações, correção e sugestões feitas no manuscrito; ao desenhista Carlos Alberto Alvarez, pelas ilustrações; ao Dr. Joaquim Gomes e $\mathrm{Dr}^{\mathrm{a}}$. Silvane Rodrigues, pela correção do manuscrito. 
À Embrapa Amazonia Oriental, ao Museu Paraense Emilio Goeldi e ao Projeto Manejo Florestal da Amazônia (MFA).

\section{Literatura citada}

Almeida, C.M., Lima, S.F., Martins-da-Silva, R.C.V. \& Gomes, J.I. 2001. Caracterização morfológica e anatomia de dez espécies de leguminosae ocorrentes em uma floresta tropical úmida localizada no município de Moju, Estado do Pará. In: J.N.M. Silva, J.O.P. Carvalho \& J.A.G. Yared (eds.). A silvicultura na Amazônia Brasileira. Embrapa Amazônia Oriental, Belém, pp. 19-54.

APG (Angiosperm Phylogeny Group). 2003. An update of the angiosperm phylogeny group classification for the orders and families of flowering plants: APG II. Botanical Juornal of the Linneaan Society 141: 399-436.

Baillon, E.H. 1876. Dictionnaire de botanique. v.4. Hachette, Paris.

Barneby, R.C., Stergios, B., Cowan, R.S., Berry, P.E., Zarucchi, J.L., Wunderlin, R.P., Kearns, D.M., Silva, M.F., Tavares, A.S., Velázquez, D., Xena, N. \& Aymard, G.A.C. 1999. Caesalpiniaceae. In: P.E. Berry, B.K. Holst \& K. Yatskieoych (eds.). Flora of the Venezuelan Guayana. Missouri Botanical Garden, Saint Louis, pp. 1-122.

Barroso, G.M., Morin, M.P., Peixoto, A.L. \& Ichaso, C.L.F. 1999. Frutos e sementes: morfologia aplicada à sistemática de dicotiledôneas. Universidade Federal de Viçosa, Viçosa.

Bentham, G. 1840. Contributions towards a flora of Souh America - Enumeration of plants collected by Mr. Schomburgk in British Guiana. Journal of Botany 2: 38-103.

Bentham, G. 1850. Journal of on excursion from Santarém, on the Amazon River, to Óbidos and the rio Trombetas. Journal of Botany 2: 93-248.

Bentham, G. 1866. Tropical Leguminosae. Transactions of the Linnean Society of London 25: 302-319.

Bentham, G. 1870. Sclerolobieae. In: C.F.P. Martius (ed.). Flora Brasiliensis. Typographia Regia, Monachii, v.15, pars. 2, pp. 46-51.

Costa, D.H.M., Ferreira, C.A.P., Silva, J.N.M., Lopes, J.C.A. \& Carvalho, J.O.P. 1998. Potencial madeireiro de floresta densa no município de Moju Estado do Pará. Documentos 121. Embrapa-CPATU, Belém.

Cowan, R.S. 1953. Leguminosae-Caesalpinioideae \& Leguminosae-Papilionatae. In: B. Maguire R.S. Cowan \& J.J. Wurdack (eds.). The Botany of the Guayana Highland. A report of the Kunhardt, the Phelps and the New York Botanical Garden Venezuelan Expeditions. Memoirs of the New York Botanical Garden, New York, pp. 103-119.
Doyle, J.J. 1994. Phylogeny of the legume family: an approach to understading the origins of nodulation. Annual Review of Ecology and Systematics 25: 325-349.

Doyle, J.J., Chappill, J.A., Bailey C.D. \& Kajita, T. 2000. Towards a comprehensive phylogeny of legumes: evidence from $r b c \mathrm{~L}$ sequences and non-molecular data. In: P.S. Herendeen \& A. Bruneau (eds.). Advances in Legume Systematics. Royal Botanic Gardens, Kew, pp. 1-20.

Ducke, A. 1922. As leguminosas do Estado do Pará. Archivos do Jardim Botânico do Rio de Janeiro 3: 91-92.

Ducke, A. 1944. New or noteworthy Leguminosae of the brazilian Amazon. Boletim Técnico do Instituto Agronômico 2: 1-33.

Ducke, A. 1949. As leguminosas da Amazônia brasileira. Archivos do Jardim Botânico do Rio de Janeiro 18: 1-248.

Dwyer, J.D. 1954. The tropical genus Tachigali Aubl. (Caesalpiniaceae). Annals of the Missouri Botanical Garden 41: 233-255.

Dwyer, J.D. 1957. The tropical American genus Sclerolobium Vogel (Caesalpiniaceae). Lloydia 20: 67-117.

Freitas, A.P.F.T. 2009. Flórula fanerogâmica das restingas do Estado do Pará: Leguminosae-Caesalpinoideae. Dissertação de Mestrado, Museu Paraense Emilio Goeldi, Belém.

Gonçalves, E.G. \& Lorenzi, H. 2007. Morfologia vegetal: organografia e dicionário ilustrado de morfologia das plantas vasculares. Instituto Plantarum de Estudos da Flora, Nova Odessa.

Harris, J.G. \& Harris, M.W. 2001. Plant identification terminology: an illustrated glossary. Spring Lake Publishing, Utah.

Huber, J. 1906. Sobre os gêneros Vouacapoua, Vatairea e Andira. Boletim do Museu Paraense de Historia Natural e Ethnographia 6: 69-473.

Huber, J. 1909. Novitates florae Amazonicae. Boletim do Museu Paraense de Historia Natural e Ethnographia 6: 79.

Irwin, H.S. 1966. Contributions to the botany of Guiana. IV. Leguminosae-Caesalpinioideae. Memoirs of the New York Botanical Garden 15: 112-128.

Killeen, T.J., García, E.G. \& Beck, G.S. 1993. Guía de Arboles de Bolivia. Herbário Nacional de Bolivia, Missouri Botanical Garden, La Paz.

Lewis, G.P. \& Polhill, R.M. 1998. A situação atual da sistemática de Leguminosae neotropicais. Monographs in Systematics Botany from the Missouri Botanical Garden 68: 113-145.

Lewis, G.P. 1987. Legumes of Bahia. Royal Botanic Gardens, Kew. 
Lewis, G.P. 2010. Libidibia. In: Forzza, R.C.; Leitman, P.M.; Costa, A.F.; Carvalho Jr., A.A.; Peixoto, A.L.; Walter, B.M.T.; Bicudo, C.; Zappi, D.; Costa, D.P.; Lleras, E.; Martinelli, G.; Lima, H.C.; Prado, J.; Stehmann, J.R.; Baumgratz, J.F.A.; Pirani, J.R.; Sylvestre, L.; Maia, L.C.; Lohmann, L.G.; Queiroz, L.P.; Silveira, M.; Coelho, M.N.; Mamede, M.C.; Bastos, M.N.C.; Morim, M.P.; Barbosa, M.R.; Menezes, M.; Hopkins, M.; Secco, R.; Cavalcanti, T.B. \& Souza, V.C. (eds). Lista de Espécies da Flora do Brasil. Jardim Botânico do Rio de Janeiro, Rio de Janeiro. http://floradobrasil. jbrj.gov.br/2010/FB109830 (acesso em 01.06.2010).

Lewis, G.P., Schire, B.D., Mackinder, B.A. \& Lock, J.M. 2005. Legumes of the World. RoyalBotanic Gardens, Kew.

Lima, H.C. 2010a. Batesia. In: Forzza, R.C.; Leitman, P.M.; Costa, A.F.; Carvalho Jr., A.A.; Peixoto, A.L.; Walter, B.M.T.; Bicudo, C.; Zappi, D.; Costa, D.P.; Lleras, E.; Martinelli, G.; Lima, H.C.; Prado, J.; Stehmann, J.R.; Baumgratz, J.F.A.; Pirani, J.R.; Sylvestre, L.; Maia, L.C.; Lohmann, L.G.; Queiroz, L.P.; Silveira, M.; Coelho, M.N.; Mamede, M.C.; Bastos, M.N.C.; Morim, M.P.; Barbosa, M.R.; Menezes, M.; Hopkins, M.; Secco, R.; Cavalcanti, T.B. \& Souza, V.C. (eds). Lista de Espécies da Flora do Brasil. Jardim Botânico do Rio de Janeiro, Rio de Janeiro. http://floradobrasil. jbrj.gov.br/2010/FB109830 (acesso em 03.10.2010).

Lima, H.C. 2010b. Campsiandra. Lista de Espécies da Flora do Brasil. Jardim Botânico do Rio de Janeiro, Rio de janeiro. http://floradobrasil.jbrj.gov.br/2010/ FB082740 (acesso em 03.10.2010).

Lima, H.C. 2010c. Tachigali. In: Forzza, R.C.; Leitman, P.M.; Costa, A.F.; Carvalho Jr., A.A.; Peixoto, A.L.; Walter, B.M.T.; Bicudo, C.; Zappi, D.; Costa, D.P.; Lleras, E.; Martinelli, G.; Lima, H.C.; Prado, J.; Stehmann, J.R.; Baumgratz, J.F.A.; Pirani, J.R.; Sylvestre, L.; Maia, L.C.; Lohmann, L.G.; Queiroz, L.P.; Silveira, M.; Coelho, M.N.; Mamede, M.C.; Bastos, M.N.C.; Morim, M.P.; Barbosa, M.R.; Menezes, M.; Hopkins, M.; Secco, R.; Cavalcanti, T.B. \& Souza, V.C. (eds). Lista de Espécies da Flora do Brasil. Jardim Botânico do Rio de Janeiro, Rio de Janeiro. http:// floradobrasil.jbrj.gov.br/2010/FB109830 (acesso em 13.10.2010).

Lima, H.C. 2010d. Vouacapoua. In: Forzza, R.C.; Leitman, P.M.; Costa, A.F.; Carvalho Jr., A.A.; Peixoto, A.L.; Walter, B.M.T.; Bicudo, C.; Zappi, D.; Costa, D.P.; Lleras, E.; Martinelli, G.; Lima, H.C.; Prado, J.; Stehmann, J.R.; Baumgratz, J.F.A.; Pirani, J.R.; Sylvestre, L.; Maia, L.C.; Lohmann, L.G.; Queiroz, L.P.; Silveira, M.; Coelho, M.N.; Mamede, M.C.; Bastos, M.N.C.; Morim, M.P.; Barbosa, M.R.; Menezes, M.; Hopkins, M.; Secco, R.; Cavalcanti, T.B. \& Souza, V.C. (eds). Lista de Espécies da Flora do Brasil. Jardim Botânico do Rio de Janeiro, Rio de Janeiro. http:// floradobrasil.jbrj.gov.br/2010/FB109830 (acesso em 13.10.2010).
Lima, H.C., Queiroz, L.P., Morim, M.P., Souza, V.C., Dutra, V.F., Bortoluzzi, R.L.C., Iganci, J.R.V., Fortunato, R.H., Vaz, A.M.S.F., Souza, E.R., Filardi, F.L.R., Valls, J.F.M., Garcia, F.C.P., Fernandes, J.M., Martins-da-Silva, R.C.V., Perez, A.P.F., Mansano, V.F., Miotto, S.T.S., Tozzi, A.M.G.A., Meireles, J.E., Lima, L.C.P., Oliveira, M.L.A.A., Flores, A.S., Torke, B.M., Pinto, R.B., Lewis, G.P., Barros, M.J.F., Ribeiro, R.D., Schütz, R., Pennington, T., Klitgaard, B.B., Rando, J.G., Scalon, V.R., Cardoso, D.B.O.S., Costa, L.C., Silva, M.J., Moura, T.M., Barros, L.A.V., Silva, M.C.R., Queiroz, R.T., Sartori A.L.B. \& Camargo, R. 2010e. Fabaceae. Lista de espécies da flora do Brasil. Jardim Botânico do Rio de Janeiro, Rio de Janeiro. http://floradobrasil.jbrj.gov.br/2010/ FB000115 (acesso em 01.06.2010).

Lorenzi, H. 2002. Árvores Brasileiras: manual de identificação e cultivo de plantas arbóreas nativas do Brasil. Editora Plantarum, Nova Odessa.

Macbride, J.F. 1943. Flora of Peru: Leguminosae. Publications of the Field Museum of Natural History 13: 1-506.

Martins-da-Silva, R.C.V., Pereira, J.F. \& Lima, H.C. 2008. O gênero Copaifera (LeguminosaeCaesalpinioideae) na Amazônia brasileira. Rodriguésia 59: 455-476.

Martius, C.F.P. 1828. Reise in Brasilien. Lindauer, Munchen.

Mori, S.A., Silva, L.A.M., Lisboa, G. \& Coradin, L. 1985. Manual de manejo de herbário fanerogâmico. Comissão Executiva do Plano da Lavoura Cacaueira, Ilhéus.

Oliveira Filho, A.T. 2006. Catálogo das árvores nativas de Minas Gerais: mapeamento e inventário da flora nativa e dos reflorestamentos de Minas Gerais. Universidade Federal de Lavras, Lavras.

Polhill, R.M. \& Vidal, J.E. 1981. Caesalpinieae. In: R.M. Polhill \& P.H. Raven (eds.). Advances in Legume Systematics: part 1. Royal Botanic Gardens, Kew, pp. 81-95.

Prance, G.T. \& Silva, M.F. 1975. Árvores de Manaus. Instituto Nacional de Pesquisas da Amazônia, Manaus.

Queiroz, L.P. 2009. Leguminosas da Caatinga. Universidade Estadual de Feira de Santana, Feira de Santana.

Ribeiro, J.E.L. do S., Hopkins, M.J.G., Vicentini, A., Sothers, C.A., Costa, M.A. da S., Brito, J.M., Souza, M.A.D., Martins, L.H.P., Lohmann, L.G., Assunção, P.A.C.L., Pereira, E. da C., Silva, C.F., Mesquita, M.R. \& Procópio, L.C. 1999. Flora da Reserva Ducke: guia de identificação das plantas vasculares de uma floresta de terra firme na Amazônia Central. Instituto Nacional de Pesquisas da Amazônia, Manaus.

Rizzini, C.T. \& Mors, W.B. 1995. Botânica econômica brasileira. Âmbito Cultural, Rio de Janeiro. 
Rizzini, C.T. 1990. Árvores e madeiras úteis do Brasil: manual de dendrologia brasileira. Edgard Blucher, São Paulo.

Rudas, A. 1997. Fabaceae. In: R.M. Vásquez (ed.). Flórula de las Reservas Biológicas de Iquitos, Perú. Monographs in Systematic Botany from the Missouri Botanical Garden, Missouri Botanical Garden, St. Louis, pp. 301-314.

SEPOF. 2009. Estatística estadual. Secretaria de Estado e Planejamento, Orçamento e Finança. http:www.sepof. pa.gov.br (acesso em 01.06.2009).

Serrão, D.R., Jardim, F.C.S. \& Nemer, T.C. 2003. Sobrevivência de seis espécies florestais em uma área explorada seletivamente no município de Moju, Pará. Cerne 9: 153-163.

Silva, L.F.G. \& Lima, H.C. 2007. Mudanças nomenclaturais no gênero Tachigali Aubl. (LeguminosaeCaesalpinioideae) no Brasil. Rodriguésia 58: 397-401.

Silva, M.F. 1986. Dimorphrandra (Caesalpiniaceae). Flora Neotropica Monograph 44: 1-128.

Silva, M.F., Carreira, L.M.M., Tavares, A.S., Ribeiro, I.C., Jardim, M.A.G., Lobo, M.G.A. \& Oliveira, J.O. 1989. As leguminosas da Amazônia Brasileira. Lista prévia. Acta Botanica Brasilica 2: 193-237.

Souza, V.C. \& Lorenzi, H. 2005. Botânica Sistemática: guia ilustrado para identificação das famílias de angiospermas da flora brasileira, baseado em APG II. 4 ed. Editora Plantarum, Nova Odessa.

Spruce, R. 1865. Batesia. In: G. Bentham \& J.D. Hooker (eds.). Ordo LVII: Leguminosae. Genera Plantarum. Sistens Dicotyledonum Polypetalarum Ordines XI: Leguminosas-Myrtaceas. Lovell Reeve e Co. London, v.1, n.2, pp. 434-600.
Stearn, W.T. 1998. Botanical Latim. 4 ed. David \& Charles, London.

Stergios, B. 1996. Contributions to South Americam Caesalpiniaceae. II. A taxonomic update of Campsiandra (Caesalpineae). Novon 6: 34-459.

Taubert, P. 1891. Leguminosae. In: A. Enghler \& K. Prantl (eds.). Die natürlichen Pflanzenfamilien. v.3. Wilhelm Engelman, Leipzig.

Tropicos. 2010. http://www.tropicos.org (acesso em 13.07. 2010).

Tulasne, M.L.R. 1844. Légumineuses arborescentes de I' Amerique du Sud. Archives du Muséum D'Histoire Naturelle 4: 123-170.

Ulibarri, E.A. 2008. Los gêneros de Caesalpinioideae (Leguminosae) presentes em Sudamerica. Darwiniana 46: 69-163.

Van der Werff, H. 2008. A synopsis of the genus Tachigali (Leguminosae: Caesalpinioideae) in northern South America. Annals of the Missouri Botanical Garden 95: 618-660.

Zarucchi, J. \& Herendeen, P. 1993. Tachigali (Fabaceae). In: L. Brako \& J. Zarucchi (eds.). Catalogue of the flowering plants and Gymnosperms of Peru. v. Monographs in Systematic Botany from the Missouri Botanical Garden v.45, pp. 1254-1255.

Zarucchi, J. \& Pipoly, J.J. 1995. Validation of Tachigali micropetala (Ducke) Zarucchi \& Pipoly (Fabaceae: Caesalpinioideae). Sida 16: 787. 